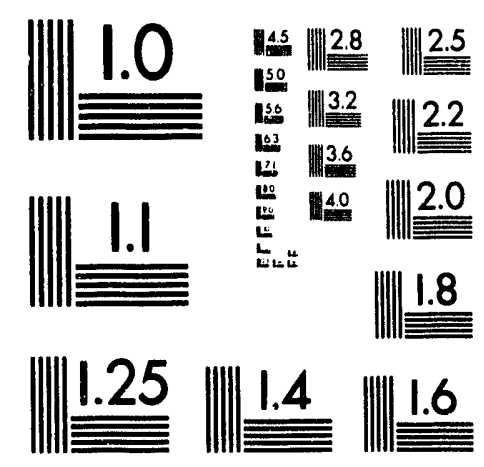



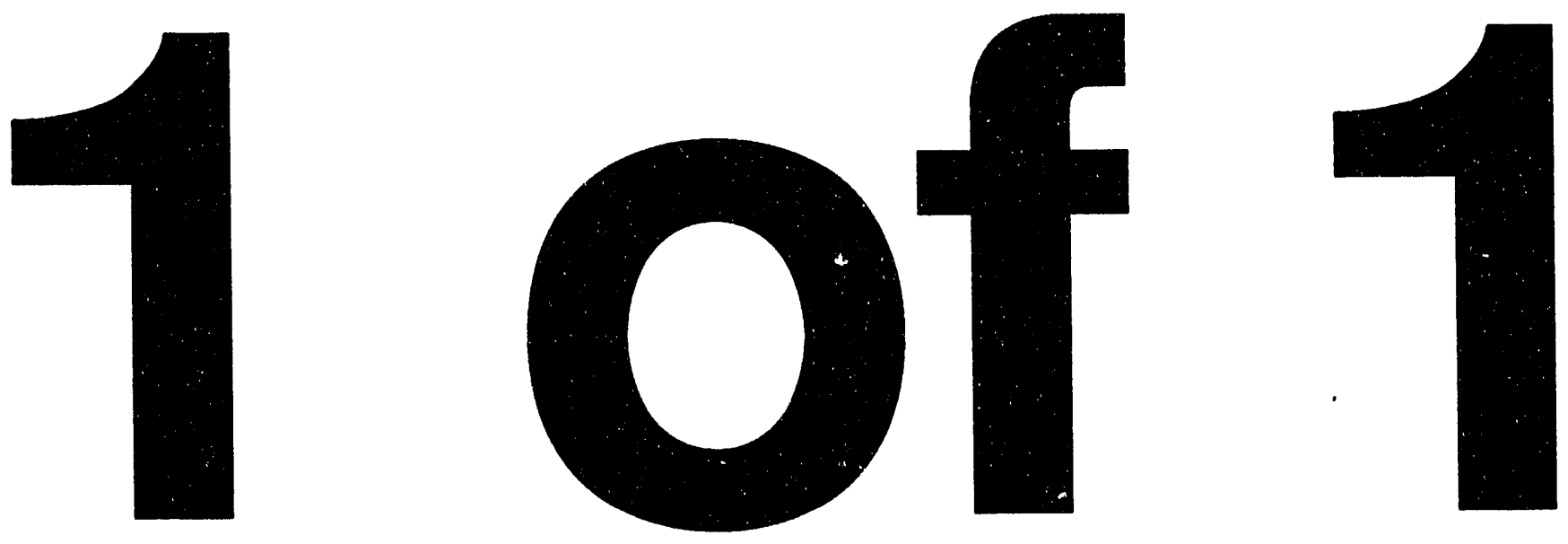


\section{FOUR MILE CREEK SEMI-ANNUAL SAMPLING REPORT: JANUARY 1993 SAMPLING EVENT (U)}

by

WSRC Contact - K. Dixon

Westinghouse Savannah River Company

Savannah River Site

Aiken, South Carolina 29808

Metcalf \& Eddy, Inc.

This paper was prepared in connection with work done under the above contract number with the $U$. S. Department of Energy. By acceptance of this paper, the publisher and/or recipient acknowledges the U. S. Government's right to retain a nonexclusive, royalty-free license in and to any copyright covering this paper, along with the right to reproduce and to authorize others to reproduce all or part of the copyrighted paper. 
Submitted to:

Westinghouse Savannah River Company

Aiken, South Carolina

\section{Four Mile Creek}

Semi-Annual

Sampling Report

January 1993

Sampling Event

Contract No. AA46327P

Task No. 26

May 1993

Submitted by:

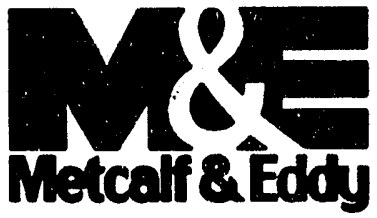




\section{DISCLAIMER}

This report was prepared as an account of work sponsored by an agency of the United States Government. Neither the United States Government nor any agency thereof, nor any of their employees, makes any warranty, express or implied, or assumes any legal liability or responsibility for the accuracy, completeness, or usefulness of any information, apparatus, product, or process disclosed, or represents that its use would not infringe privately owned rights. Reference herein to any specific commercial product, process, or service by trade name, trademark, manufacturer, or otherwise does not necessarily constitute or imply its endorsement, recommendation, or favoring by the United States Government or any agency thereof. The views and opinions of authors expressed herein do not necessarily state or reflect those of the United States Government or any agency thereof.

This report has been reproduced directly from the best available copy.

Available to DOE and DOE contractors from the Office of Scientific and Technical Information, P. O. Box 62, Oak Ridge, TN 37831; prices available from (615) $576-8401$.

Available to the public from the National Technical Information Service, U. S. Department of Commerce, 5285 Port Royal Rd., Springfield, VA 22161. 
Four Mile Creek

Semi-Annual Sampling Report

January 1993 Sampling Event

Submitted May 6, 1993

TABLE OF CONTENTS

$1.0 \quad$ INTRODUCTION $\ldots \ldots \ldots \ldots \ldots \ldots \ldots \ldots \ldots \ldots \ldots \ldots \ldots \ldots \ldots$

2.0 EXPERIMENTAL METHODS $\ldots \ldots \ldots \ldots \ldots \ldots \ldots \ldots \ldots \ldots \ldots$

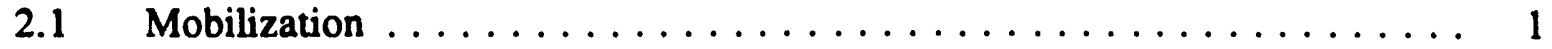

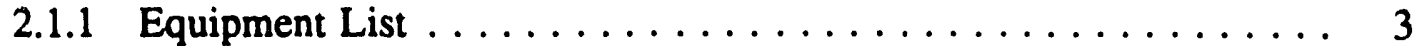

2.1.2 Decontamination Procedures . . . . . . . . . . . . . . . 4

2.2 Sample Collection Procedures $\ldots \ldots \ldots \ldots \ldots \ldots \ldots \ldots \ldots \ldots, 4$

2.2.1 Groundwater ..................... 4

2.2.2 Surface Water Sampling $\ldots \ldots \ldots \ldots \ldots \ldots \ldots \ldots \ldots$

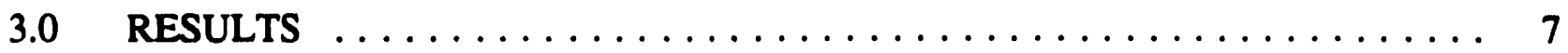

4.0 CONCLUSIONS $\ldots \ldots \ldots \ldots \ldots \ldots \ldots \ldots \ldots \ldots \ldots \ldots \ldots \ldots \ldots$

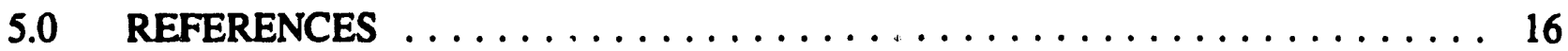

APPENDIX A Chain-of-custody records

APPEINDIX B Metcalf \& Eddy Surveillance

\section{LIST OF TABLES}

1.1. Sample Location Numbers and SRS Coordinates $\ldots \ldots \ldots \ldots \ldots \ldots$

2.1. Duplicate and Triplicate Samples $\ldots \ldots \ldots \ldots \ldots \ldots \ldots \ldots \ldots \ldots$

3.1. Water Quality Parameters Measured in the Field $\ldots \ldots \ldots \ldots \ldots \ldots \ldots$

4.1. Summary of Conductivity Measurements $\ldots \ldots \ldots \ldots \ldots \ldots \ldots \ldots$

4.2. Summary of $\mathrm{pH}$ Measurements $\ldots \ldots \ldots \ldots \ldots \ldots \ldots \ldots \ldots \ldots \ldots \ldots$ 
Four Mile Creek

Semi-Annual Sampling Report

January 1993 Sampling Event

Submitted May 6, 1993

\section{LIST OF FIGURES}

4-1. Conductivity Measurements in H-Area $\ldots \ldots \ldots \ldots \ldots \ldots \ldots$

4-2. Conductivity Measurements in F-Area $\ldots \ldots \ldots \ldots \ldots \ldots \ldots$

4-3. $\mathrm{pH}$ Measurements in $\mathrm{H}-$ Area $\ldots \ldots \ldots \ldots \ldots \ldots \ldots \ldots \ldots \ldots$

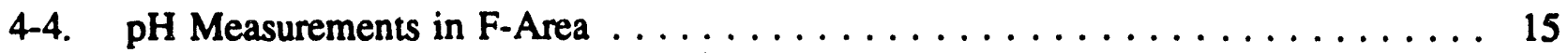


Four Mile Creek

Semi-Annual Sampling Report

January 1993 Sampling Event

Submitied May 6, 1993

\subsection{INTRODUCTION}

From 1955 to 1988 low-level radioactive wastewater generated by chemical separation processes within the General Separations Area (GSA) was discharged to seepage basins in the $\mathrm{F}$ and $\mathrm{H}$ Areas of the Savannah River Site (SRS). These basins were designed to permit the infiltration of the process wastewaters. As wastewater percolated downward through the basins, chemical and radioactive constituents were retained or sequestered in the subsoils.

An extensive study aimed at characterizing the groundwater seeping into Four Mile Creek and its associated seepline was conducted in 1988 and 1989 (Haselow et al. 1990). Results of this study suggested that contaminants leaching from the $F$ and $H$ Area seepage basins were impacting the Four Mile Creek wetland system. The seepage basins were closed in 1988 and capped and sealed in 1990 . This effectively eliminated the source of the contaminants and the hydraulic head driving the migration of contaminants from the basins. It has been hypothesized that, after the elimination of the source and head, annual rainfall amounts would be sufficient to dilute and flush out contaminants remaining in the subsoils and groundwaters beneath the basins. Westinghouse Savannah River Company has designed a semi-annual sampling and analytical program for the Four Mile Creek (FMC) seepline and stream water to test the hypothesis.

Twelve (12) seepline water and four (4) stream water sampling locations are included in the semi-annual monitoring. These sampling locations include three (3) background locations. Sampling locations were selected by WSRC based on previous sampling results. Sampling location numbers and SRS coordinates are presented in Table 1.1.

The first of the three scheduled semi-annual sampling events took place from July 20, 1992 through July 29, 1992. A report dated October 1992 presents the field results associated with the first sampling event. The second of the three scheduled semi-annual sampling events took place from January 25, 1993 through February 4, 1993. This report summarizes the results of the field monitoring obtained during this second event and presents a brief comparison to previous data.

\subsection{EXPERIMENTAL METHODS}

\subsection{Mobilization}

Labeled sample bottles, with preservatives added as necessary, "blue ice", and coolers were provided by the following pairs of subcontracted analytical laboratories: General Engineering Laboratories (non-radiological analyses)/Environmental Physics(radiological analyses); and 
Four Mile Creek

Semi-Annual Sampling Report January 1993 Sampling Event Submitted May 6, 1993

Roy F. Weston (non-radiological analyses)/Clemson Technical Center(radiological analyses). Additional bottles for on-site analysis of total activity were supplied by the WSRC-EMS Radiological Laboratory. WSRC provided chain-of-custody forms.

Table 1.1. Sample Location Numbers and SRS Coordinates

\begin{tabular}{lll} 
& \multicolumn{2}{l}{ SRS Coordinates } \\
Seepline & North & East \\
H-Area & 71005 & 56990 \\
HSP008 & 71278 & 56257 \\
HSP029 & 71644 & 55722 \\
HSP043 & 71629 & 55190 \\
HSP060 & 72672 & 54129 \\
HSP092 & & \\
F-Area & & \\
FSP012 & 73602 & 49644 \\
FSP032 & 73367 & 50258 \\
FSP047 & 73609 & 50607 \\
FSP204 & 73281 & 48801 \\
FSP290 & 73160 & 46865 \\
Background & & \\
BG001 & & \\
BG002 & Seepline & \\
BG003 & Seepline \\
Stream Sites & Stream water \\
FMC0001H & & \\
FMC0002H & & \\
FMC0001F & 70350 & 57050 \\
& 72600 & 53000 \\
& 72200 & 43900 \\
\hline
\end{tabular}

'The locations of background samples were within the grid identified by Site Use Grid Maps 13 and 14 as $71750 \mathrm{~N}$ and $40000 \mathrm{E}$ and $70000 \mathrm{E}$. The exact location was identified by ESS technical personnel. 
Four Mile Creek

Semi-Annual Sampling Report January 1993 Sampling Event

Submitted May 6, 1993

The sample bottles needed for one day of sampling were separated by station and carried to the sampling station.

\subsubsection{Equipment List}

The following equipment was used during seepline groundwater sampling:

Rubber gloves

Safety glasses

Clipboard, waterproof pens, waterproof markers

Field data logbook

Chain-of-custody forms

Shipping orders

Sample bottles

Backpacks

Shovel, post-hole digger, hatchet or axe

Peristaltic pump

Paper and cloth towels

7iplock bags

Coolers with cool packs

Bubble pack

Sampling buckets (5-gallon) with lids

Water quality meters (pH, conductivity)

Silicone (Silastic) tubing

1 one-liter Nalgene bottle for each station sampled

0.45 micron filters and filtering equipment

Tyvek aprons

The following equipment was used during stream water sampling:

Rubber gloves

Safety glasses

Clipboard, waterproof pens, waterproof markers

Field data logbook

Chain-of-custody forms

Shipping orders

Sample bottles

Backpacks

Paper and cloth towels 
Four Mile Creek

Semi-Annual Sampling Report

January 1993 Sampling Event

Submitted May 6, 1993

Ziplock bags

Coolers with cool packs

Bubble pack

Water quality meters ( $\mathrm{pH}$, conductivity)

1 one-liter Nalgene bottle for each station sampled

0.45 micron filters and filtering equipment

Life jackets

Hip boots

Tyvek aprons

\subsubsection{Decontamination Procedures}

Cleaning and decontamination procedures for all sampling equipment are outlined below. All sampler parts were decontaminated prior to the collection of each sample.

Sampling equipment was first cleaned with Milli-Q water and phosphate-free laboratory detergent (Liquinox) using a brush if necessary to remove particulate matter and surface films. The equipment was then rinsed thoroughly with Milli-Q water. Finally, the equipment was rinsed two times with pesticide-grade methanol solvent and allowed to dir dry. The dry equipment was wrapped with aluminum foil, when possible, to prevent contamination during storage and transport.

All decontamination rinse waters were discharged to the ground. The methanol was collected in a pan and allowed to evaporate.

\subsection{Sample Collection Procedures}

\subsubsection{Groundwater}

All sample locations had been permanently marked by WSRC with a 1" Schedule 40 grey PVC stake driven 2 feet below grade. A station identification number was written on a metal tag attached to each PVC stake.

After locating the sampling station, the sampling crew excavated a hole using a decontaminated stainless steel shovel. The hole was excavated within a 3 foot radius of the PVC stake. A 5-gallon plastic sampling bucket was placed into the hole and covered with a lid. One bucket was set at each location except locations HSP008, HSPO43, FSPO47 and FSP290 where two buckets were set. The additional bucket was needed in order to collect sufficient water for duplicate and QA samples. 
Four Mile Creek

Semi-Annual Sampling Report January 1993 Sampling Event

Submitted May 6, 1993

The buckets were set out one day prior to sample collection in order to allow the sediment in the water to settle. The time between setting the bucket and sample collection was recorded in the field notebook. During this second sampling event, the $\mathrm{pH}$ of the water entering the bucket was taken at the time the bucket was set. This information was recorded in the field $\log$ book.

The $40 \mathrm{ml}$ GCMS/VOA vials and the 1-liter sample bottle, for water to be filtered for metals analysis, were filled first by dipping them into the bucket. This was done in such a manner as to avoid disturbance of the sediment. The VOA vial was filled completely so that no air bubbles were present in the sample.

The remaining samples were collected by pumping the water from the bucket to the remaining sample jars through silastic (silicone) tubing using a peristaltic pump powered by a 12-volt battery. New tubing was used for each sample location. The new tubing was flushed for 20 seconds with water from the bucket before the sampling crew collected the sample.

Samples collected for metals analysis were filtered in the field through a 0.45 micron membrane filter (to remove fine particulate matter from the water being analyzed). The filtering occurred within 4 hours of sample collection. The filtering apparatus was flushed with deionized or distilled water between filtering each sample. A battery-powered vacuum filter apparatus and $45 \mathrm{~mm}$ diameter filters were used during the first sampling event in June of 1992. An air-powered positive-pressure apparatus and $142 \mathrm{~mm}$ diameter filters were used during this second sampling event. This second method provided much more efficient filtering capabilities.

The $\mathrm{pH}$ and conductivity of the water at each location were measured at the time of sampling. These readings were taken directly from the water collected in the 5 gallon bucket and recorded in the field data logbook. The probes were rinsed with DI water prior to taling these measurements. The buckets were left in the ground at the completion of this second sampling event.

Blue ice was used to keep the samples cool from the time of sampling until they were received at the analytical laboratory.

At the following sampling locations, a $250 \mathrm{ml}$ plastic sample container was filled with the water and sent to the WSRC EMS Radiological Laboratory to determine the total activity in the samples: HSP008, HSP029, HSP060, HSP092, FSP032, FSP204, FMC001F. These data were used to determine the packaging and shipping requirements of the specific samples. 
Four Mile Creek

Semi-Annual Sampling Report January 1993 Sampling Event

Submitted May 6, 1993

The duplicate and triplicate samples ccllected during this sampling event are summarized in Table 2.1. Duplicate samples were collected at both HSP043 and FSP047 and sent to General Engineering/Environmental Physics and Roy F. Weston/Clemson for QAVQC purposes. A triplicate sample was collected from HSP008. This triplicate sample consisted of HSP008 sent to General Engineering/Environmental Physics; QA-1S sent to General Engineering/Environmental Physics and QA-1S sent to Roy F. Weston/Clemson. A triplicate sample was collected from FSP290. This triplicate sample consisted of FSP290 sent to General Engineering/Environmental Physics; QA-3S sent to General Engineering/Environmental Physics and QA-3S sent to Roy F. Weston/Clemson.

Table 2.1. Duplicate and Triplicate Samples

\begin{tabular}{|c|c|c|c|}
\hline \multirow[b]{2}{*}{ Location } & \multirow[b]{2}{*}{$\begin{array}{l}\text { Sample } \\
\text { Type }\end{array}$} & \multicolumn{2}{|c|}{$\begin{array}{l}\text { Sample Numbers and Analytical } \\
\text { Laboratory }\end{array}$} \\
\hline & & $\begin{array}{c}\text { General } \\
\text { Engineering/ } \\
\text { Environmental } \\
\text { Physics }\end{array}$ & $\begin{array}{c}\text { Roy F. } \\
\text { Weston/Clemson }\end{array}$ \\
\hline HSP043 & Duplicate & HSP043 & HSP043 \\
\hline FSP047 & Duplicate & FSP047 & FSP047 \\
\hline HSPO08 & Triplicate & $\begin{array}{l}\text { HSP0O8 } \\
\text { QA-1S }\end{array}$ & QA-1S \\
\hline FSP290 & Triplicate & $\begin{array}{l}\text { FSP290 } \\
\text { QA-3S }\end{array}$ & QA-3S \\
\hline
\end{tabular}

Two trip blanks were included for the semi-annual sampling event (QA-2S and QA-4S). Two equipment rinsate samples (QA-3 and QA-4) were collected on February 2, 1993. Two samples of Milli-Q water, one from the source (QA-1) and one from the field carboy (QA-2), were collected on February 5, 1993 and sent to General Engineering.

Initially, collected samples were transported to the Health Protection office in the Central Shops area where the outside of the containers were scanned for radioactivity prior to shipping. The purpose of this scan was to identify any radiological health hazards associated with handling the samples. The samples were then transported to the laboratory at $704 \mathrm{~B}$ where they remained until cleared for shipment. Part way through the second sampling event, 
Four Mile Creek

Semi-Annual Sampling Report

January 1993 Sampling Event

Submitted May 6, 1993

the requirement for an HP scan of the bottles was eliminated. Shipping requirements were based on total activity analysis performed on samples from the seven preselected stations listed above.

\subsubsection{Sufface Water Sampling}

Collection of the surface water samples was performed by dipping the sample container directly into the stream water. This collection method minimizes alteration of the sample. Also, the potential for sample cross contamination through the use of poorly decontaminated sampling equipment is eliminated. Sampling personnel wore hip boots and gloves to minimize exposure to potential contaminants.

The sample bottles to be used at each location were removed from the coolers and the bottle labels were completed with waterproof markers or ball point pens and covered with clear adhesive tape to prevent smudging. Surface grab samples were collected in the middle of the stream from the top of the water column. The container was placed into the water with the mouth of the container facing upstream such that water flowed directly into the container. Care was taken when opening and filling the bottles since some of the bottles contained carefully measured amounts of chemical preservatives.

All containers, except the VOA vials, were filled to the shoulder with water. VOA vials were filled completely and capped so that no air bubbles were present in the sample. Water collected for metals analysis was filtered in the field prior to preservation. The filled sample containers were capped tightly and placed in a plastic ziplock bag. The samples were placed in coolers and kept cool. The in-situ $\mathrm{pH}$ and conductivity of the stream was measured and recorded in field notebook at the time of sampling.

Evidence of sample collection, shipment, laboratory receipt and laboratory custody until sample disposal must be documented to ensure the sample traceability scheme.

Documentation was accomplished through a chain-of-custody record that contains the necessary information for individual sample identification and lists the individuals responsible for sample collection, shipment, and receipt along with necessary signatures and dates. Completed chain-of-custody forms for this sampling event are presented in Appendix A.

\subsection{RESULTS}

The $\mathrm{pH}$ and conductivity measurements collected in the field are summarized in Table 3.1. The pH readings, taken at the time the bucket was set, for the H-Area seepline samples 


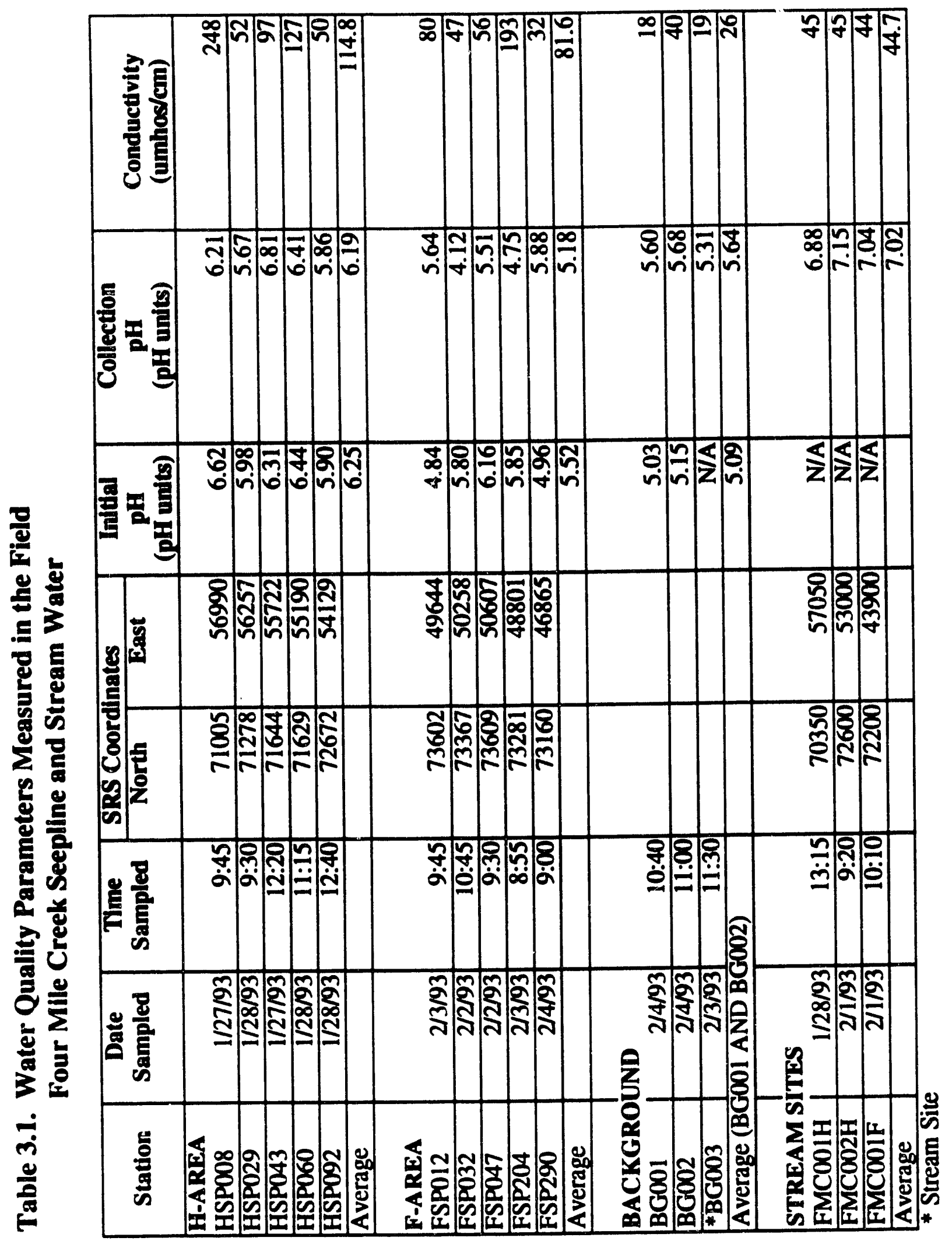


Four Mile Creek

Semi-Annual Sampling Report January 1993 Sampling Event

Submitted May 6, 1993

ranged from 5.90 to 6.62 with an average value of 6.25 . The $\mathrm{pH}$ readings, taken at the time the bucket was set, for the F-Area seepline samples ranged from 4.84 to 6.16 with an average value of 5.52. The average $\mathrm{pH}$ of the background seepline samples was 5.09, at the time the buckets were set.

The $\mathrm{pH}$ readings, taken at the time of sample collection, for the $\mathrm{H}$-Area seepline samples ranged from 5.67 to 6.81 with an average value of 6.19 . The $\mathrm{pH}$ readings, taken at the timie of sample collection, for the F-Area seepline samples ranged from 4.12 to 5.88 with an average value of 5.18. The average $\mathrm{pH}$ of the background seepline samples was 5.64, at the time of sample collection.

All conductivity readings were taken at the time of sampling. The conductivity readings for the seepline samples in the H-Area ranged from $50 \mu \mathrm{mhos} / \mathrm{cm}$ to $248 \mu \mathrm{mhos} / \mathrm{cm}$ with an average value of $114.8 \mu \mathrm{mhos} / \mathrm{cm}$. The conductivity readings for the seepline samples in the F-Area ranged from $32 \mu \mathrm{mhos} / \mathrm{cm}$ to $193 \mu \mathrm{mhos} / \mathrm{cm}$ with an average value of $81.6 \mu \mathrm{mhos} / \mathrm{cm}$. The average conductivity of the background seepline samples was $29 \mu \mathrm{mhos} / \mathrm{cm}$.

The $\mathrm{pH}$ readings for the stream samples ranged from 6.88 to 7.15 with an average value of 7.02. The $\mathrm{pH}$ of the background stream sample was 5.31. The conductivity readings for the stream samples ranged from $44 \mu \mathrm{mhos} / \mathrm{cm}$ to $45 \mu \mathrm{mhos} / \mathrm{cm}$ with an average value of 44.7 $\mu \mathrm{mhos} / \mathrm{cm}$. The conductivity of the background stream sample was $19 \mu \mathrm{mhos} / \mathrm{cm}$.

The conductivity and $\mathrm{pH}$ of the seepline water were measured previously in March of 1989 (Haselow et al., 1990), in May of 1992 (Dixon et al., 1992), and in July of 1992 (first semiannual sampling event). A summary of this previous data and the current data is presented in Tables 4.1 and 4.2 and shown graphically in Figures 4-1 through 4-4.

Figures 4-1 and 4-2 illustrate the conductivity measurements collected from the H-Area and the F-Area, respectively. A general trend of decreasing conductivity is evident in the H-Area with two minor exceptions. HSP008 and HSP092 increased slightly between July 1992 and January 1993. This decreasing trend is not seen in the F-Area. The conductivity measurements at sample locations FSP032 and FSP204 in the F-Area show a decreasing trend in conductivity. The measurements at sample location FSP012 show an increasing trend initially and then decrease between July 1992 and January 1993. The measurements at sample locations FSP047 and FSP290 show no decreasing or increasing trend. The average background conductivity of the seepline water collected during this sampling event was $\mathbf{2 9 . 5}$ $\mu$ mhos $/ \mathrm{cm}$. Ninety-six percent of the data presented in Table 4.1 exceeds this background conductivity value. 
Four Mile Creek

Semi-Annual Sampling Report January 1993 Sampling Event

Submitted May 6, 1993

Figures 4-3 and 4-4 illustrate the $\mathrm{pH}$ measurements collected from the H-Area and the FArea, respectively. No specific trend is evident in either of these figures. The average background $\mathrm{pH}$ of the seepline water collected during this sampling event was 4.91. Sixtyfive percent of the data presented in Table 4.2 has a $\mathrm{pH}$ measurement which is greater than 4.91.

The background stream measurement for $\mathrm{pH}(5.80)$ and conductivity (20 umhos/cm) was exceeded in all of the downgradient stream samples.

Metcalf \& Eddy conducted a surveillance of the sampling procedures to verify that sampling was being conducted in accordance with the approved task specific Quality Assurance Project Plan. The results of this surveillance is provided in Appendix B.

\subsection{CONCLUSIONS}

The average $\mathrm{pH}$ and conductivity values measured during this field event for the F-Area seepline samples, the H-Area seepline samples, and the stream samples are higher than the average pH and conductivity of the background seepline and stream water samples.

Whereas historical trends indicate decreasing conductivity in the H-Area seepline samples, no trends are evident in the conductivity measurements for the F-Area seepline. Historical pH measurements in both the F-Area and H-Area seepline samples show no general trends. 
Draft Four Mile Creek Semi-Annual Sampling Report January 1993 Sampling Event Submitted May 6, 1993

\section{TABLE 4.1. SUMMARY OF CONDUCTIVITY MEASUREMENTS}

\begin{tabular}{|r|r|r|r|r|r|}
\hline H-AREA & \multicolumn{7}{|c|}{ CONDUCTIVITY (umhos/cm) } \\
\cline { 2 - 7 } & HSP008 & HSP029 & HSP043 & HSPO60 & HSP092 \\
\hline Mar-89 & 556 & 257 & 413 & 473 & ND \\
\hline May-92 & 334 & 234 & 294 & 274 & ND \\
\hline Jul-92 & 237 & 97 & 155 & 173 & 33 \\
\hline Jan-93 & 248 & 52 & 97 & 127 & 50 \\
\hline
\end{tabular}

\begin{tabular}{|r|r|r|r|r|r|}
\hline \multirow{2}{*}{ F-AREA } & \multicolumn{7}{|c|}{ CONDUCTIVTY (umhos/cm) } \\
\cline { 2 - 7 } & FSP012 & FSP032 & FSP047 & FSP204 & FSP290 \\
\hline Mar-89 & 30 & 174 & 52 & 895 & 49 \\
\hline May-92 & 58 & 138 & 125 & 311 & 28 \\
\hline Jul-92 & 106 & 95 & 88 & 277 & 46 \\
\hline Jan-93 & 80 & 47 & 56 & 193 & 32 \\
\hline
\end{tabular}

TABLE 4.2. SUMMARY OF PH MEASUREMENTS

\begin{tabular}{|r|r|r|r|r|r|}
\hline H-AREA & \multicolumn{7}{|c|}{ pH } & \multicolumn{1}{|c|}{ HSP092 } \\
\cline { 2 - 7 } & HSP008 & HSP029 & HSP043 & HSPO60 & ND \\
\hline Mar-89 & 5.7 & 5.2 & 5.3 & 5.9 & ND \\
\hline May-92 & 5.6 & 6.1 & 6.2 & 5.6 & 5.68 \\
Jul-92 & 6.32 & 4.8 & 5.73 & 6.07 & 5.86 \\
Jan-93 & 6.21 & 5.67 & 6.81 & 6.41 & \\
\hline
\end{tabular}

\begin{tabular}{|r|r|r|r|r|r|}
\hline F-AREA & \multicolumn{7}{|c|}{ pH } & FSP290 \\
\cline { 2 - 7 } & FSP012 & FSP032 & FSP047 & FSP204 & 3.6 \\
\hline Mar-89 & 5.3 & 5 & 4.7 & 4.4 & 4.8 \\
\hline May-92 & 5.4 & 4.3 & 4.6 & 4.4 & 4.83 \\
\hline Jul-92 & 5.14 & 4.1 & 5.38 & 5.35 & 5.88 \\
\hline Jan-93 & 5.64 & 4.12 & 5.51 & 4.75 & \\
\hline
\end{tabular}




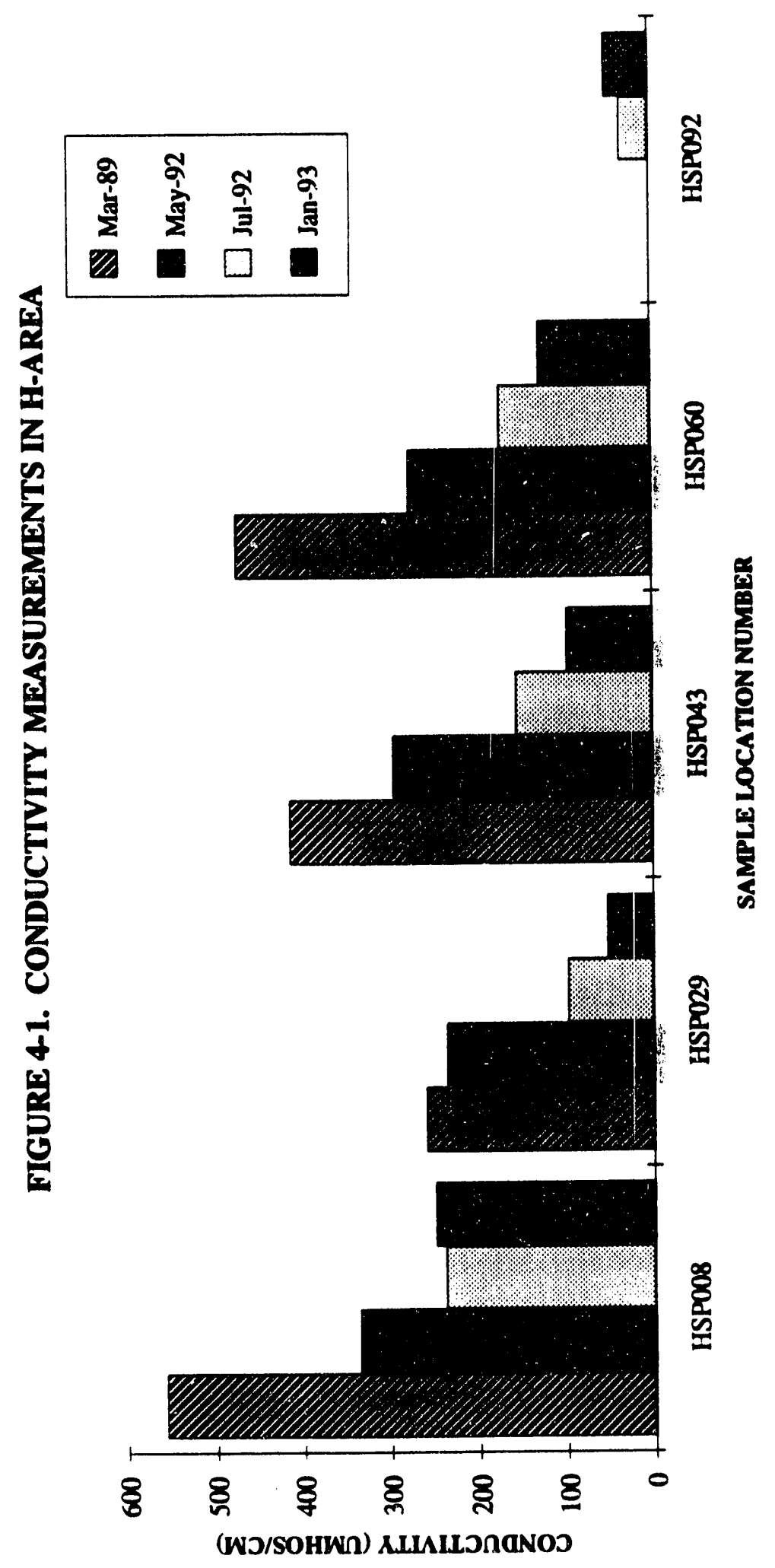




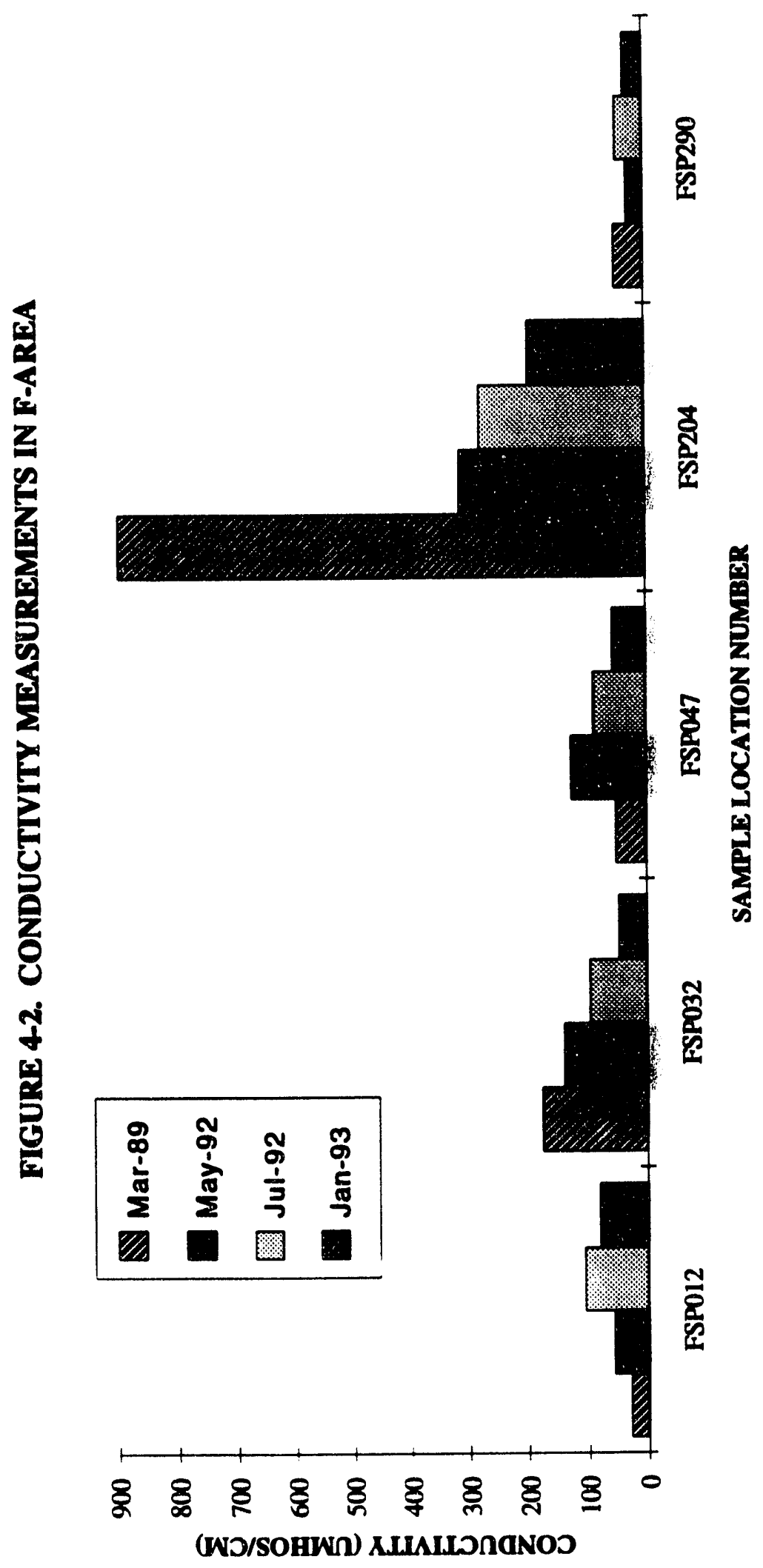




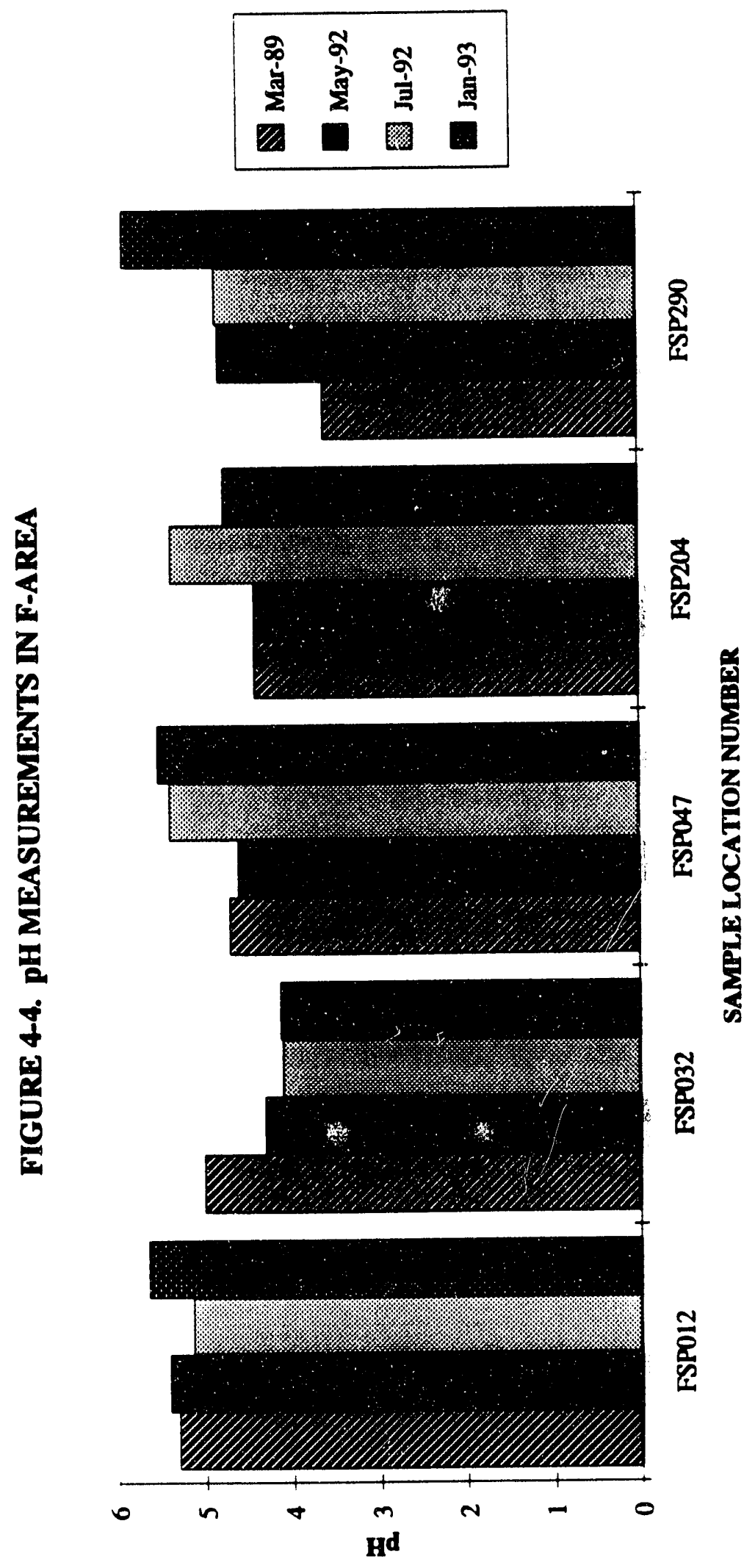




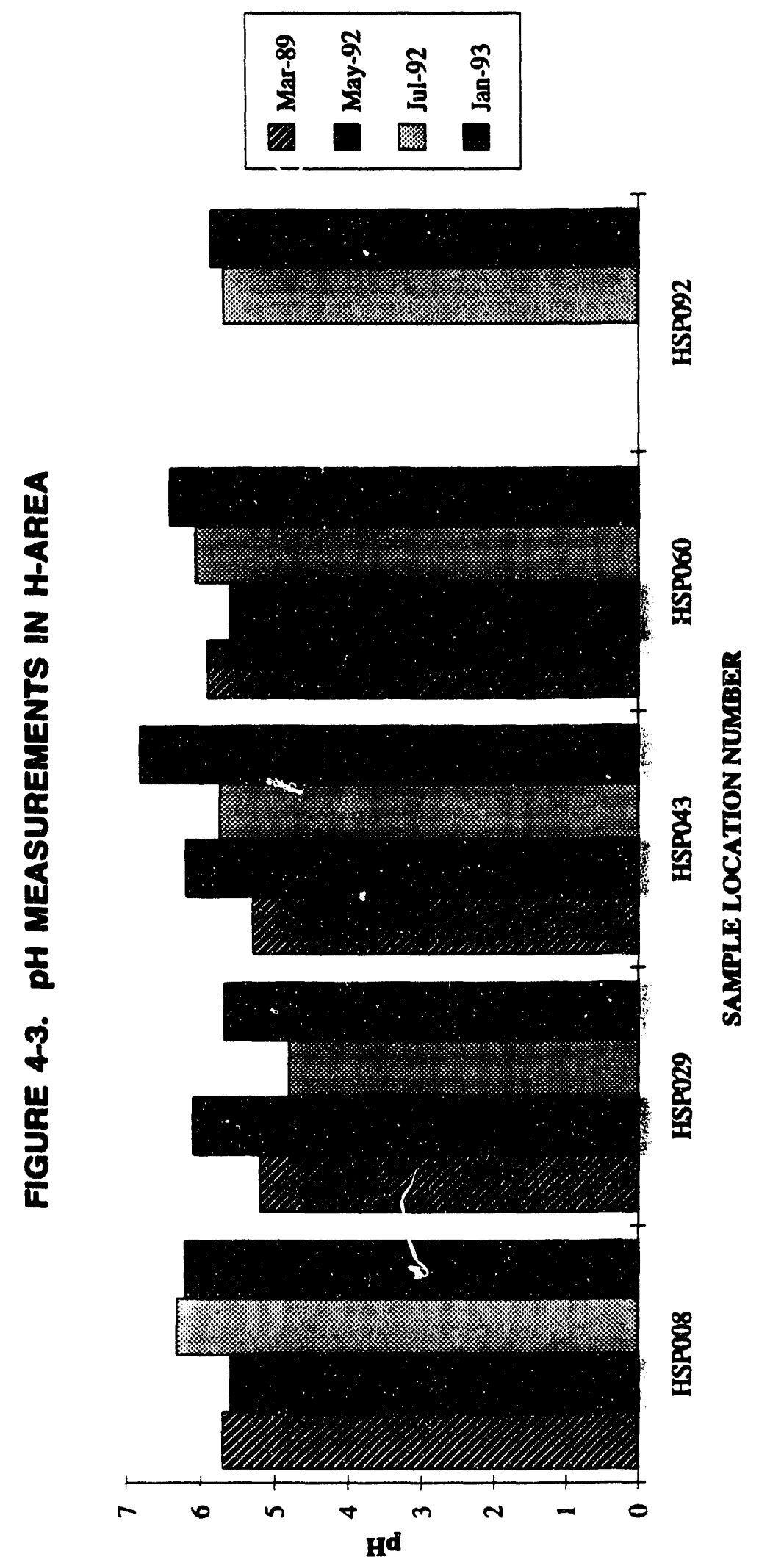


Four Mile Creek

Semi-Annual Sampling Report January 1993 Sampling Event

Submitted May 6, 1993

\subsection{REFERENCES}

Dixon, K.l. and V.A. Rogers. Results of the First Quarter Tritium Survey of the F- and HArea Seeplines: May 1992 (U). WSRC-TR-92-304, Savannh River Technology Center, Aiken, South Carolina.

Haselow, J.S., M. Harris, B.B. Looney, N.V. Halverson, J.B. Gladden. 1990. Analysis of Soil and Water at the Four Mile Creek Seepline Near the F and H Area of the SRS $(U)$. WSRCRP-90-0591, Savannah River Laboratory, Aiken, South Carolina.

Westinghouse Savannah River Company, Four Mile Creek Semi-Annual Sampling Report July 1992 Sampling Event. October 1992. 
APPENDIX A

Chain-of-custody records 


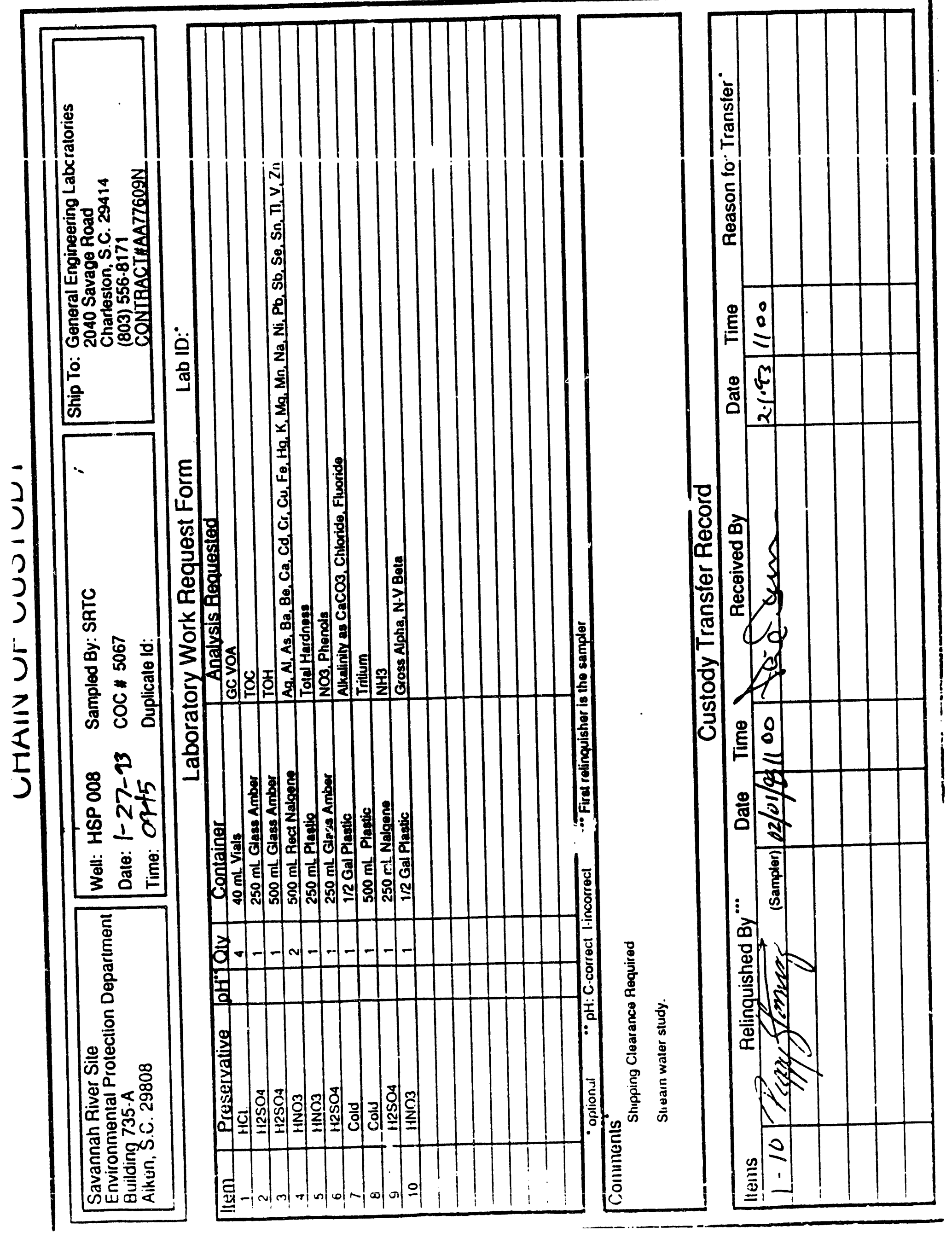




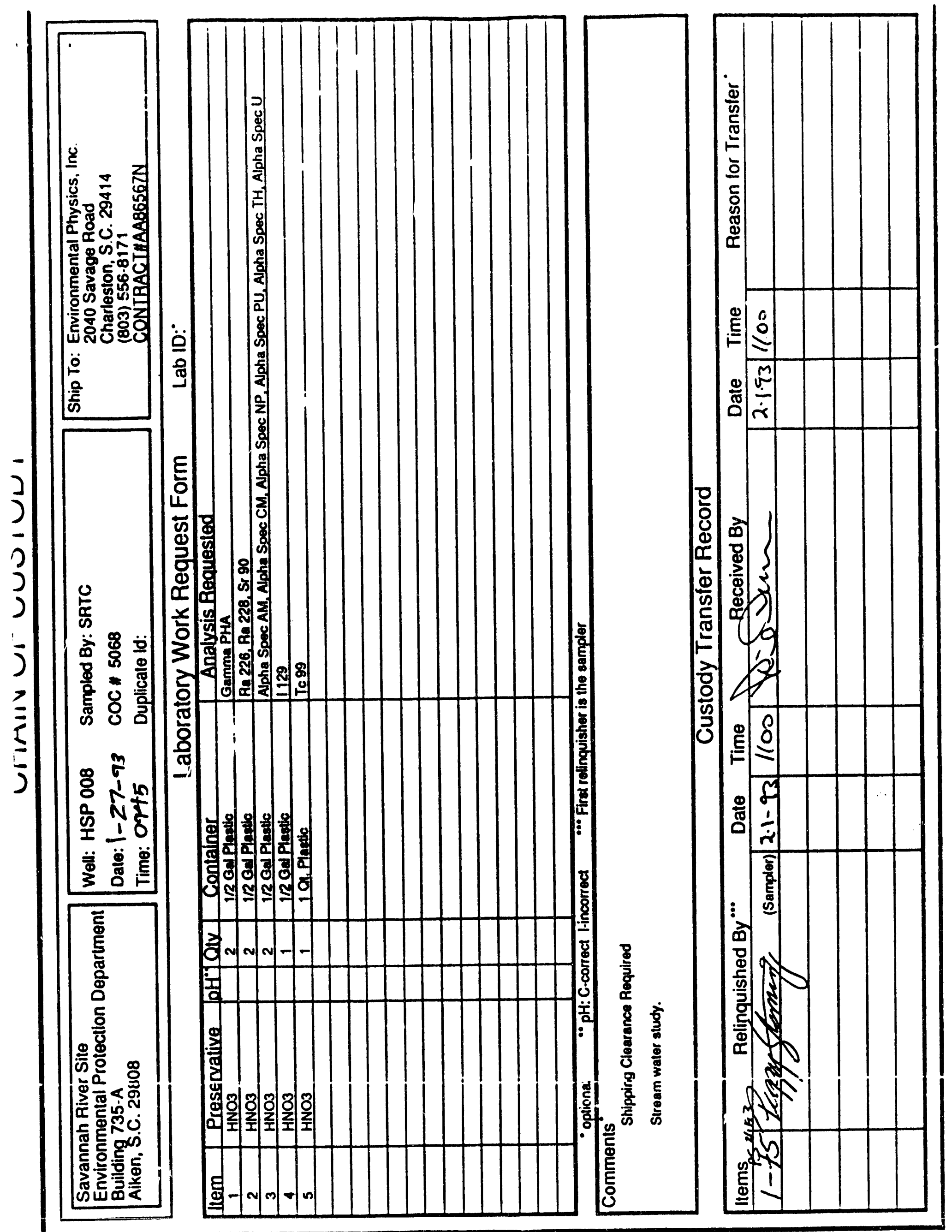




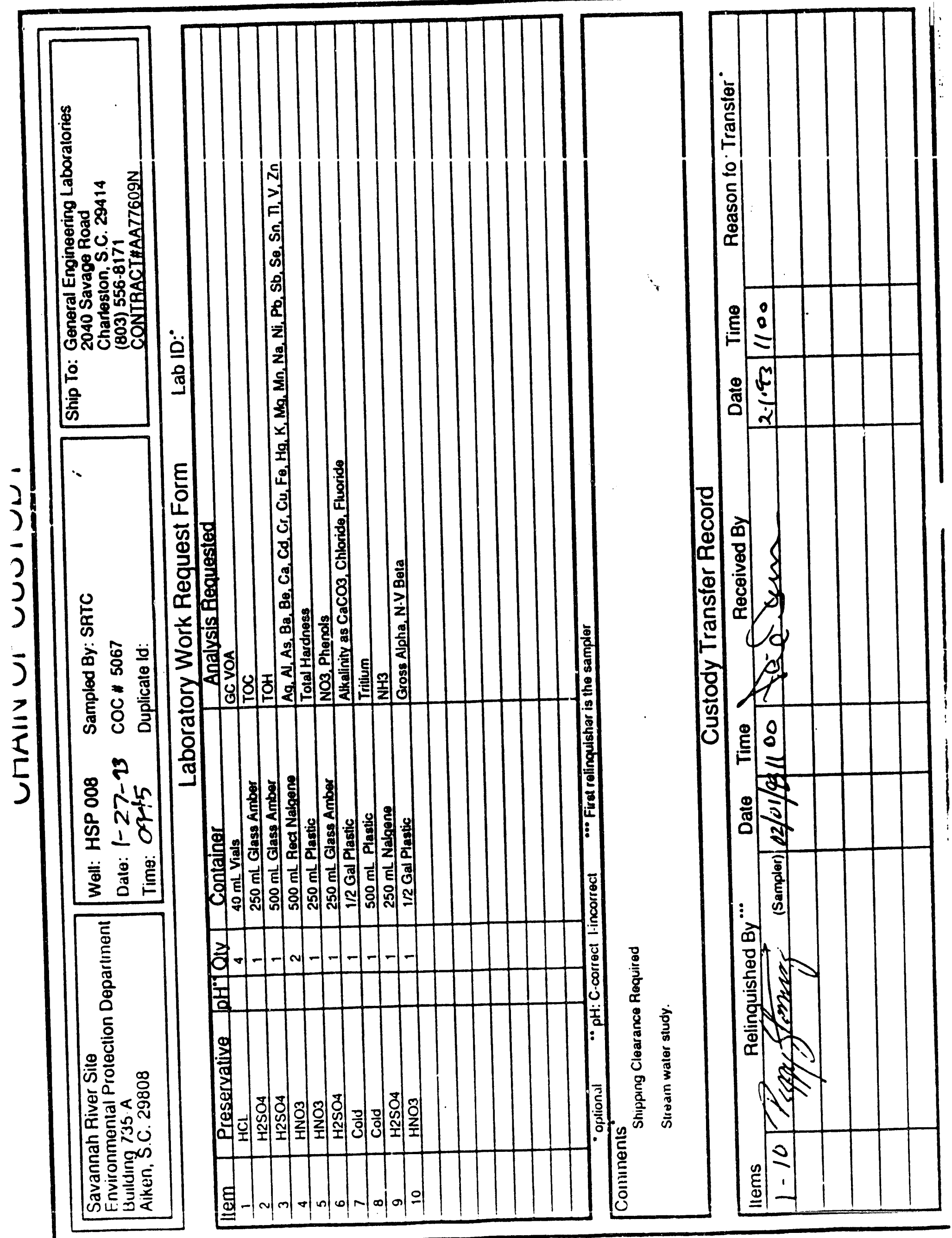




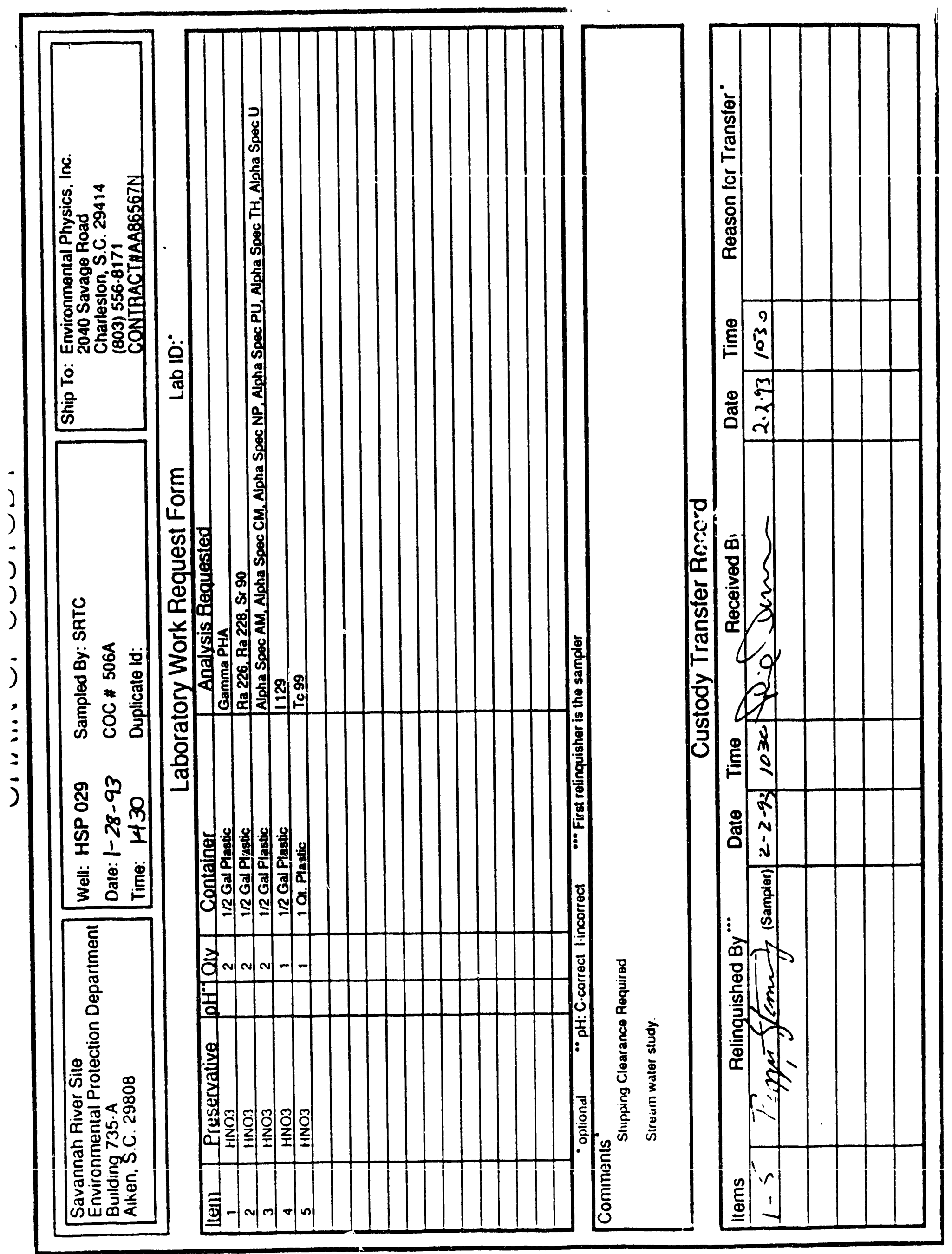




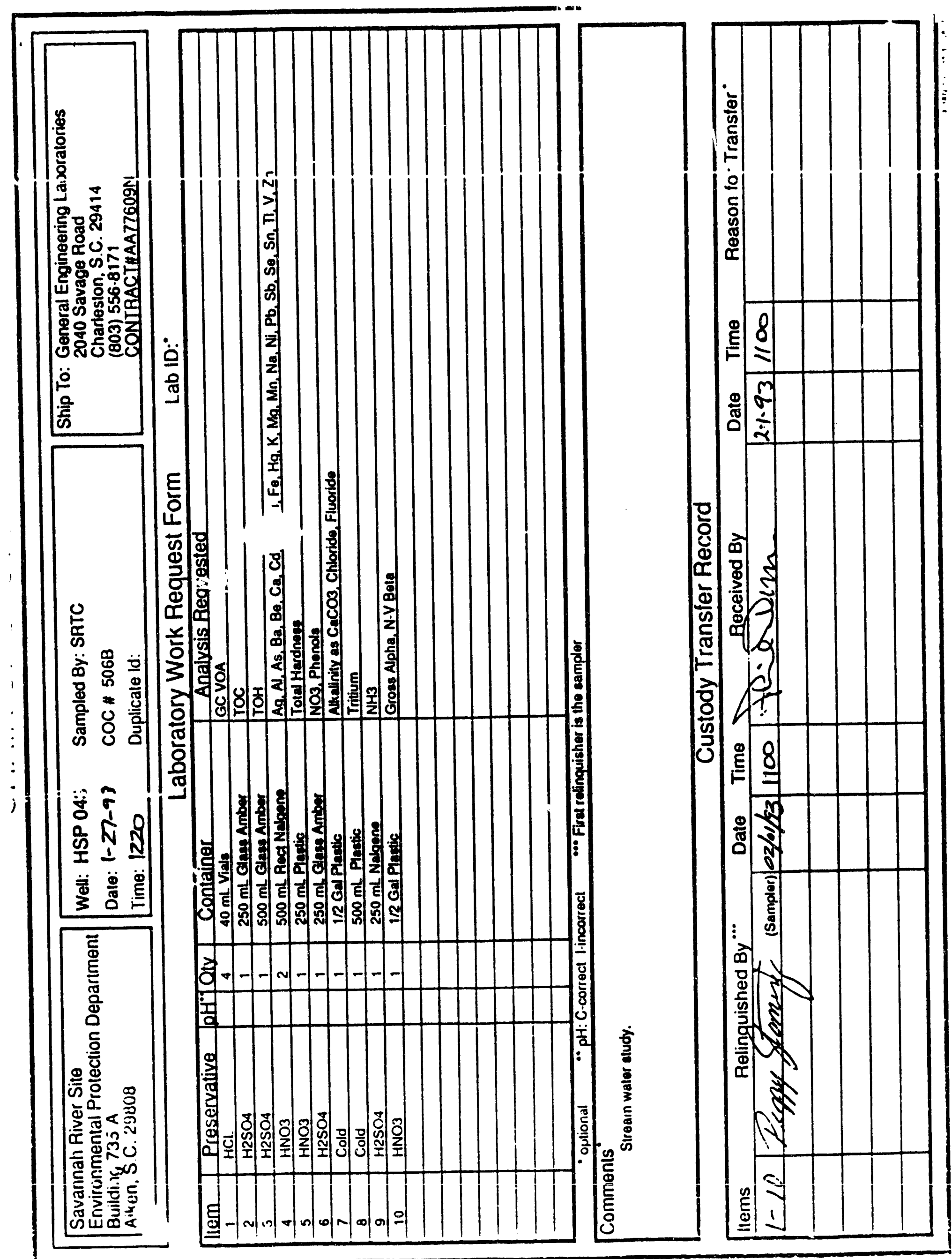




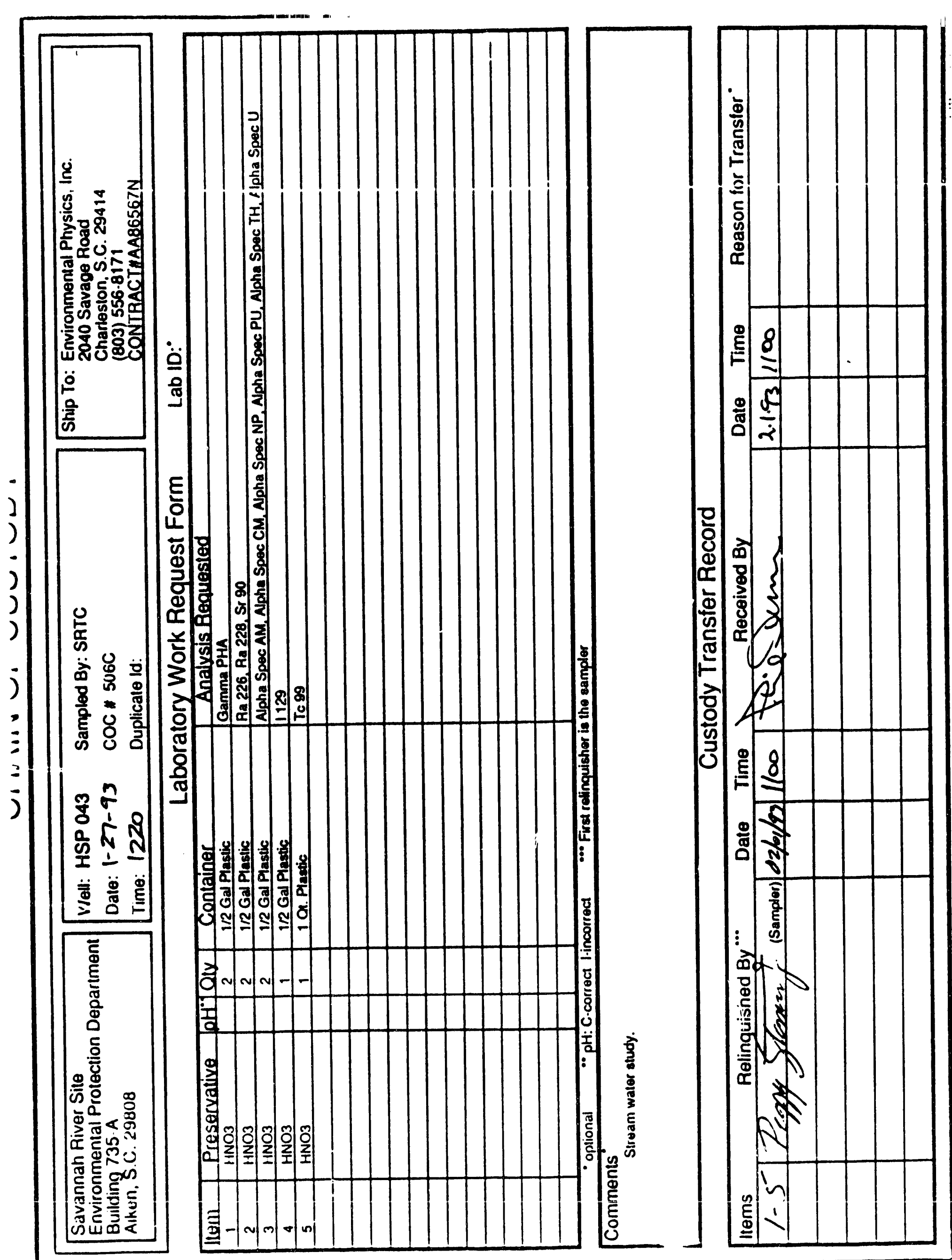




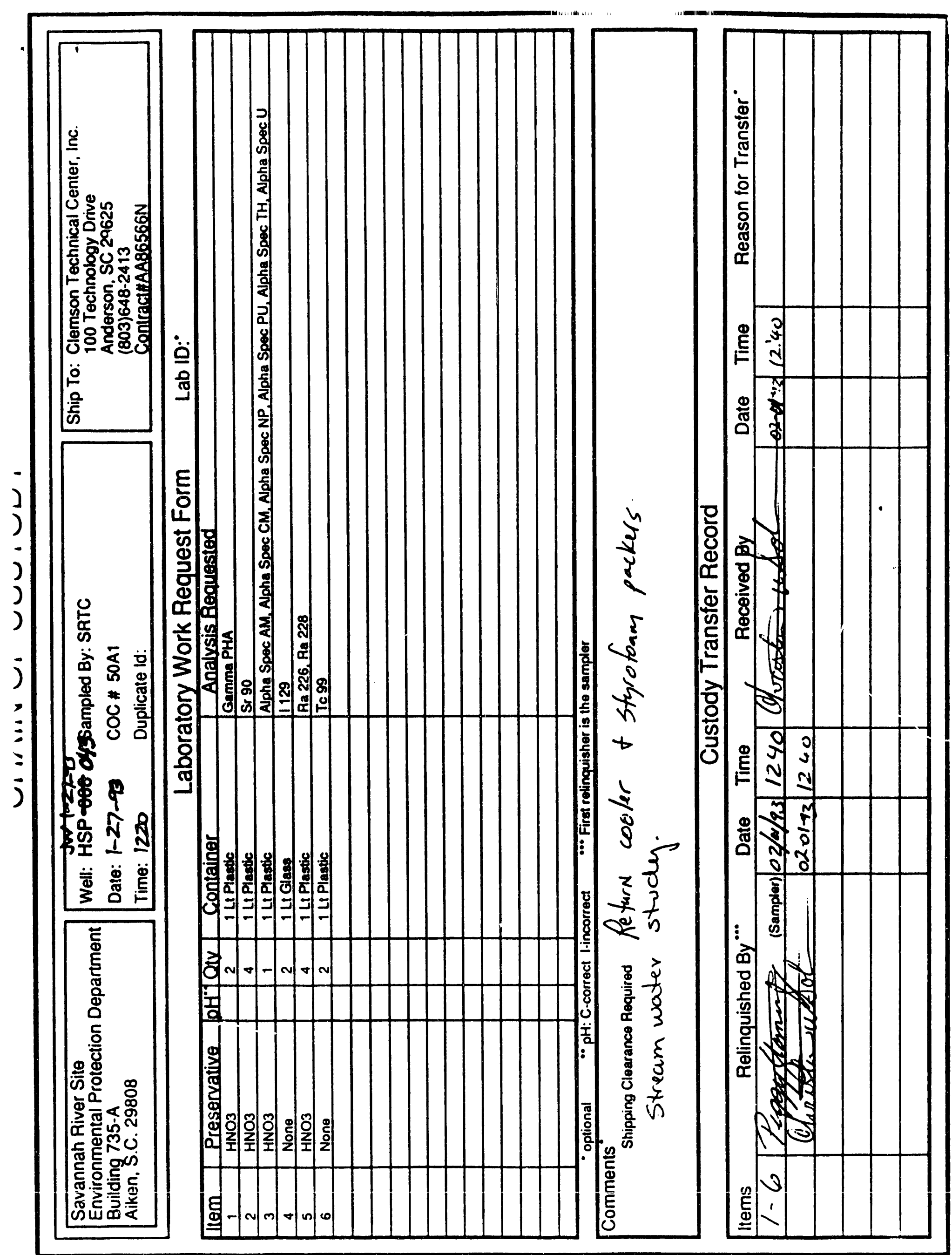




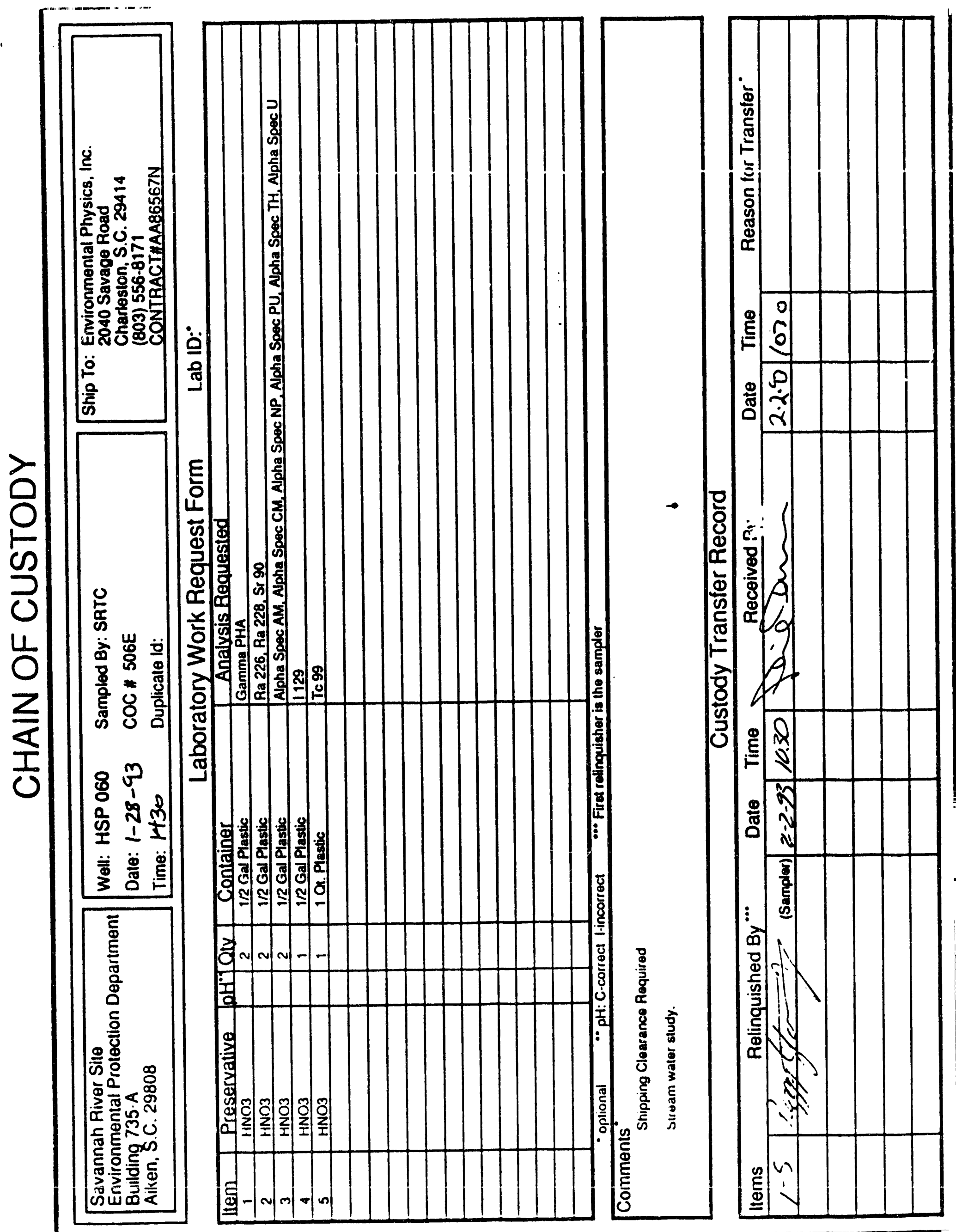




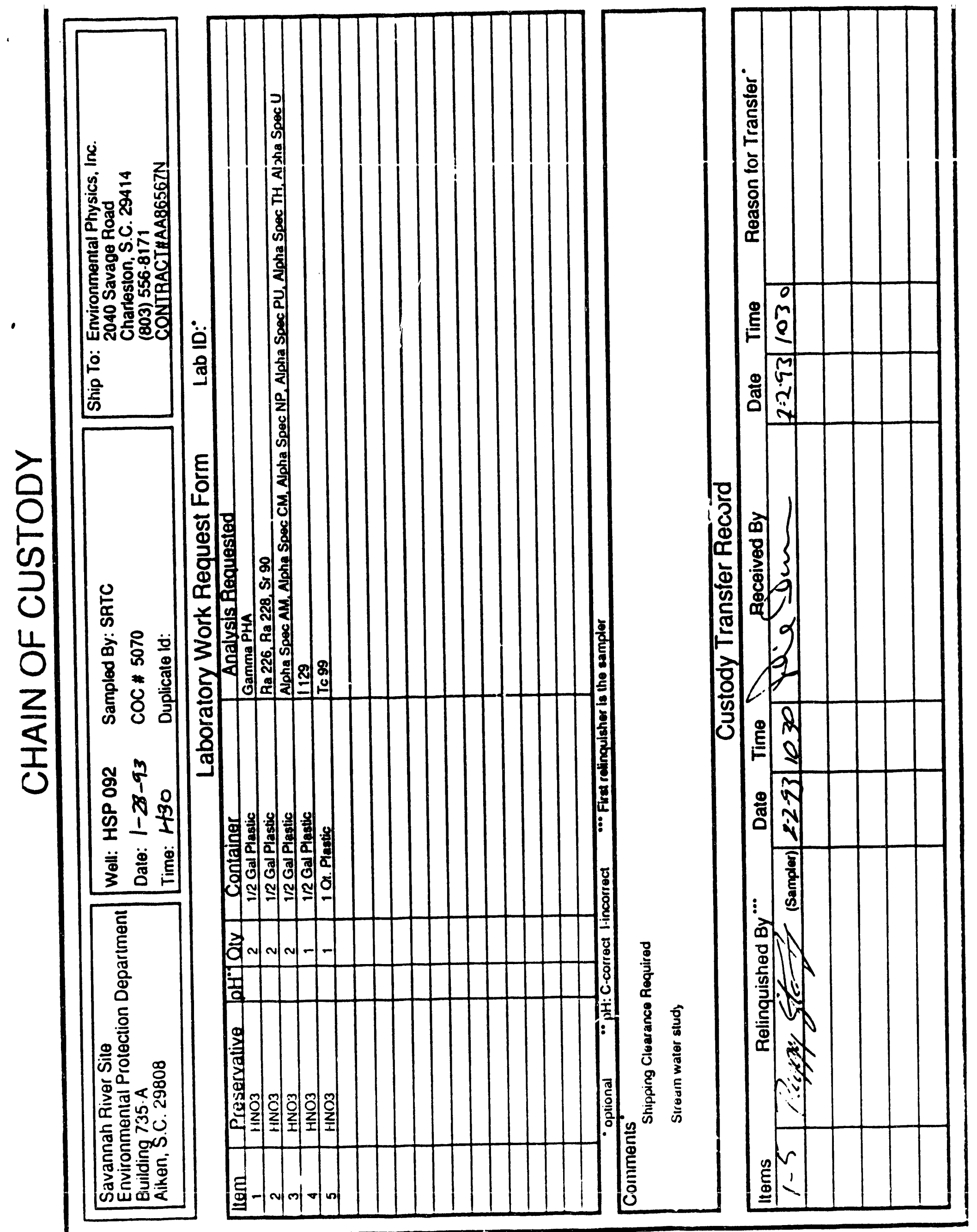




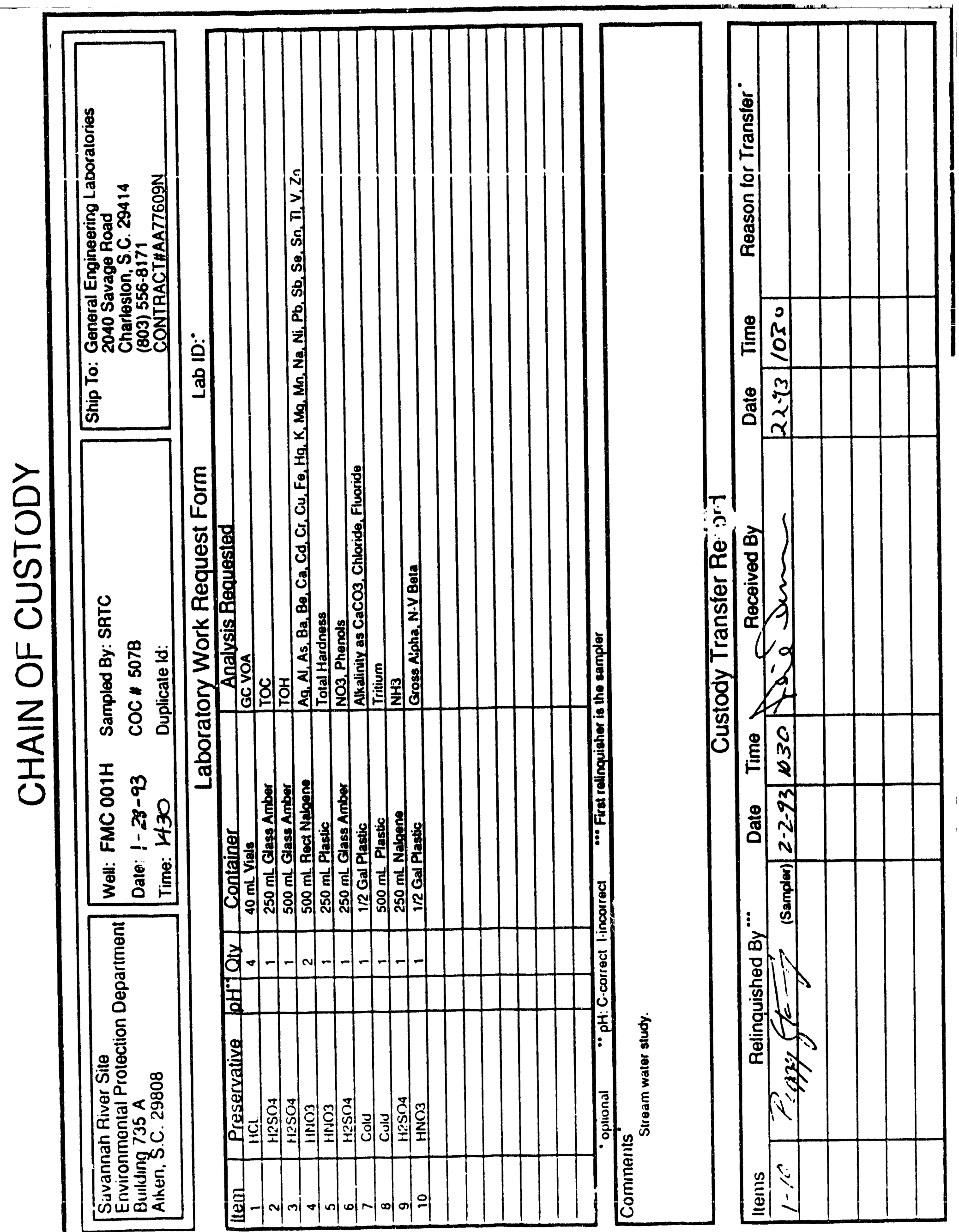




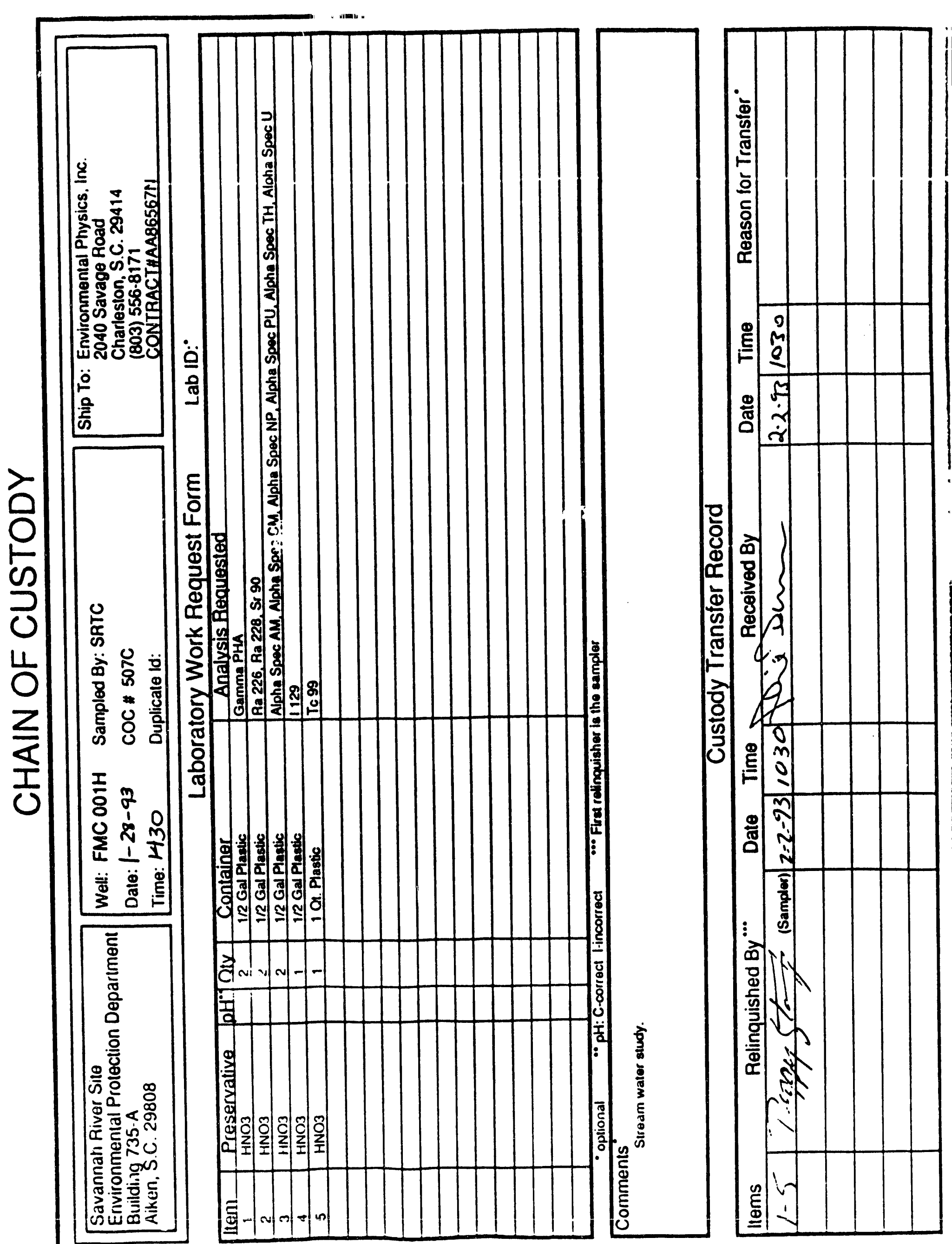




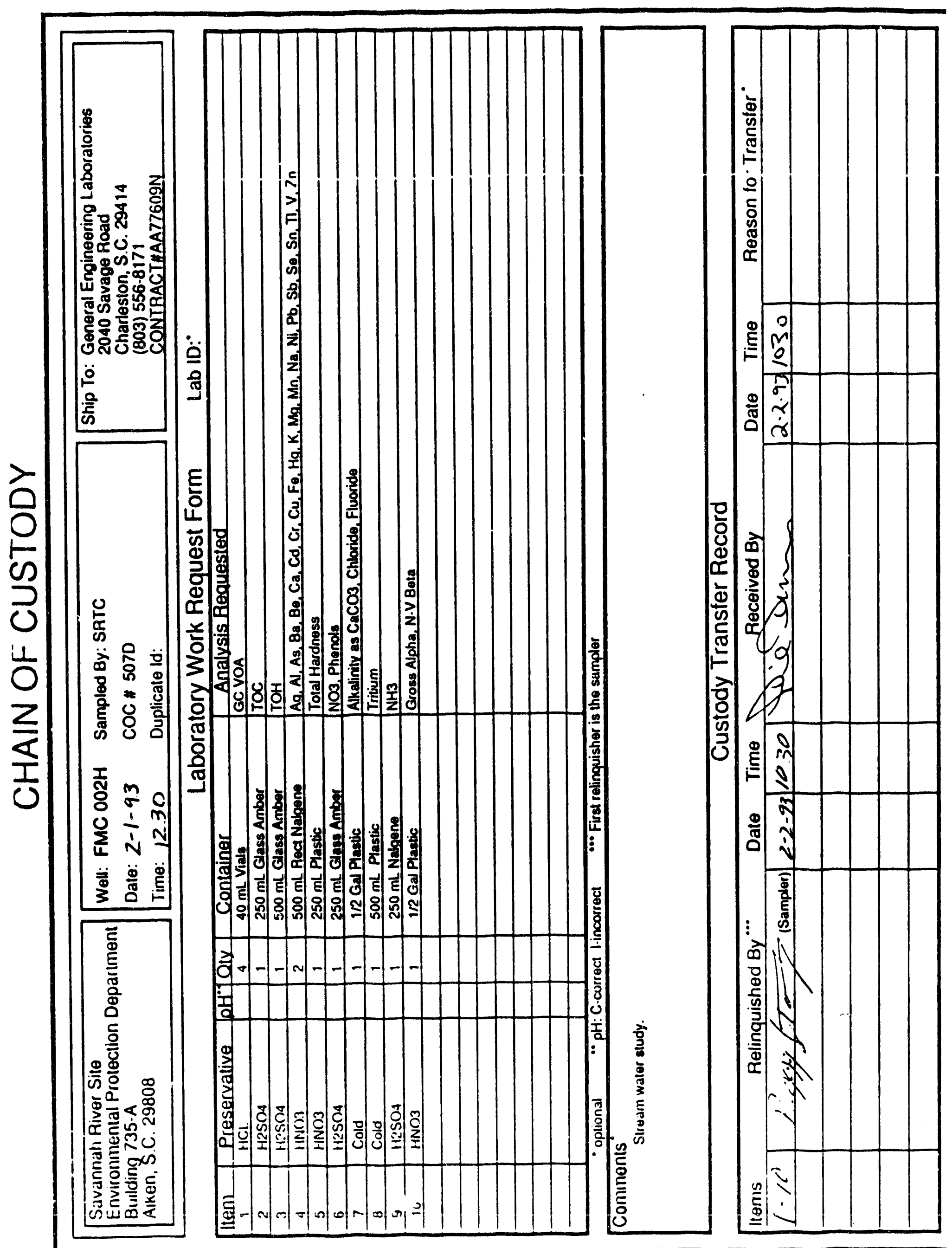




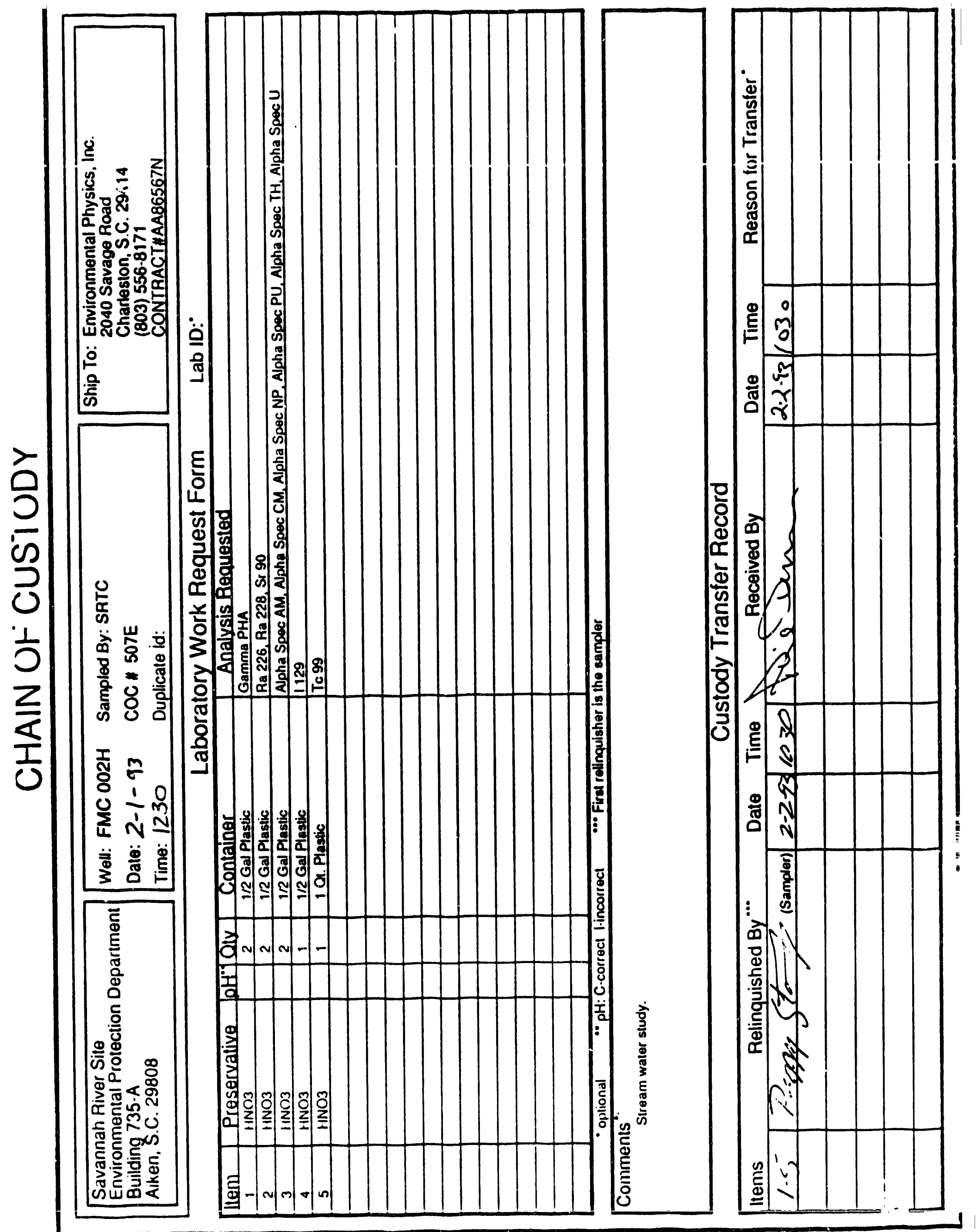




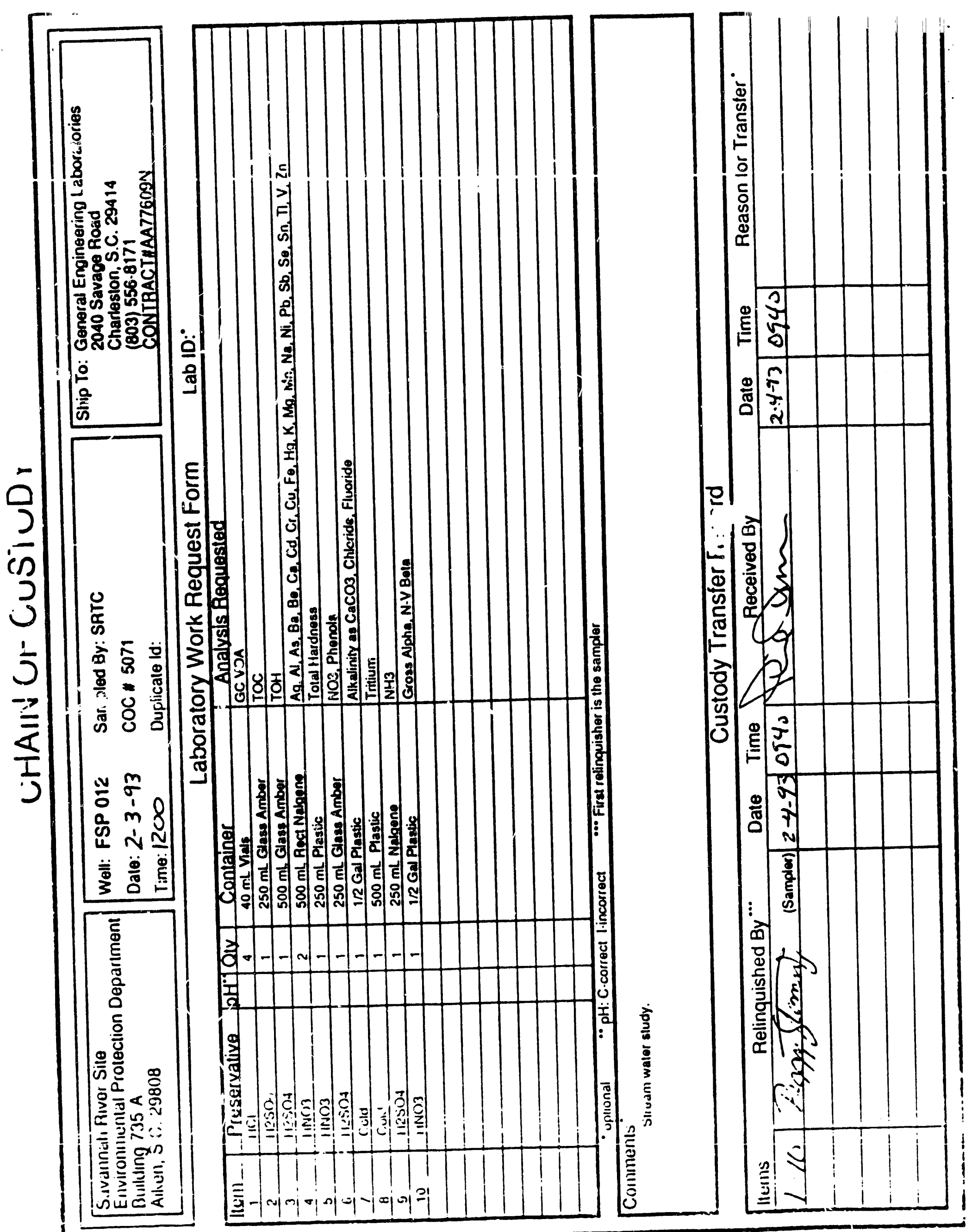




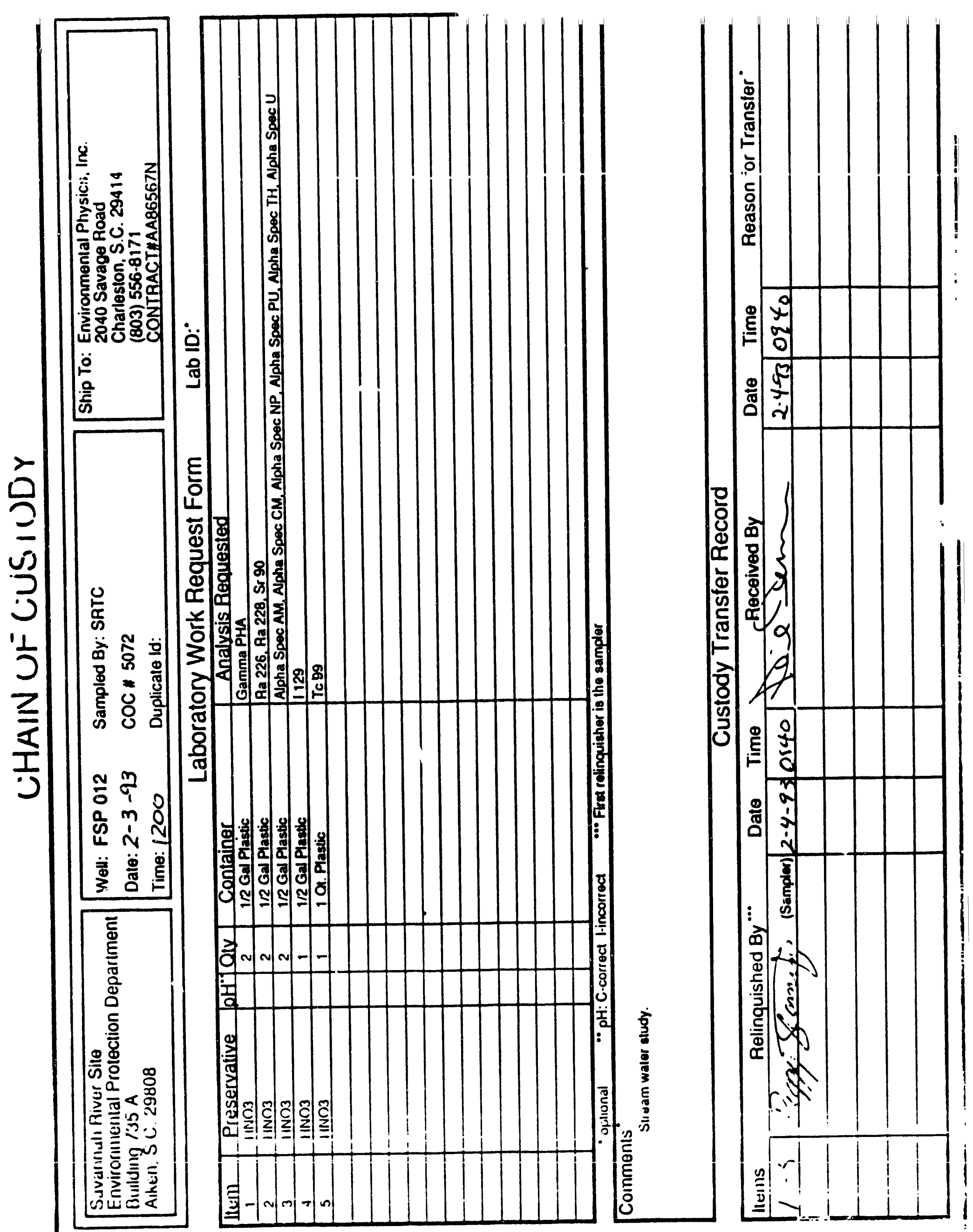




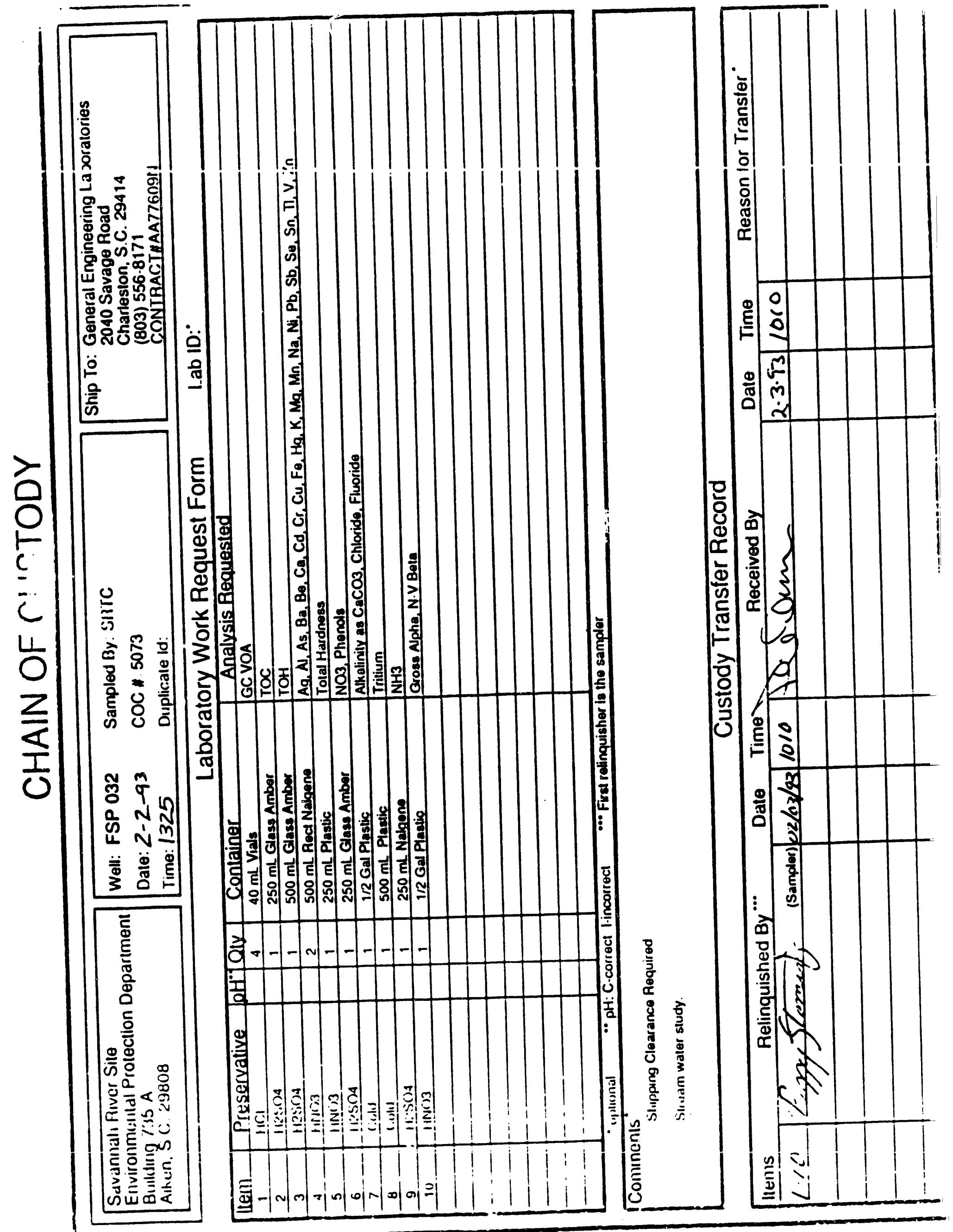




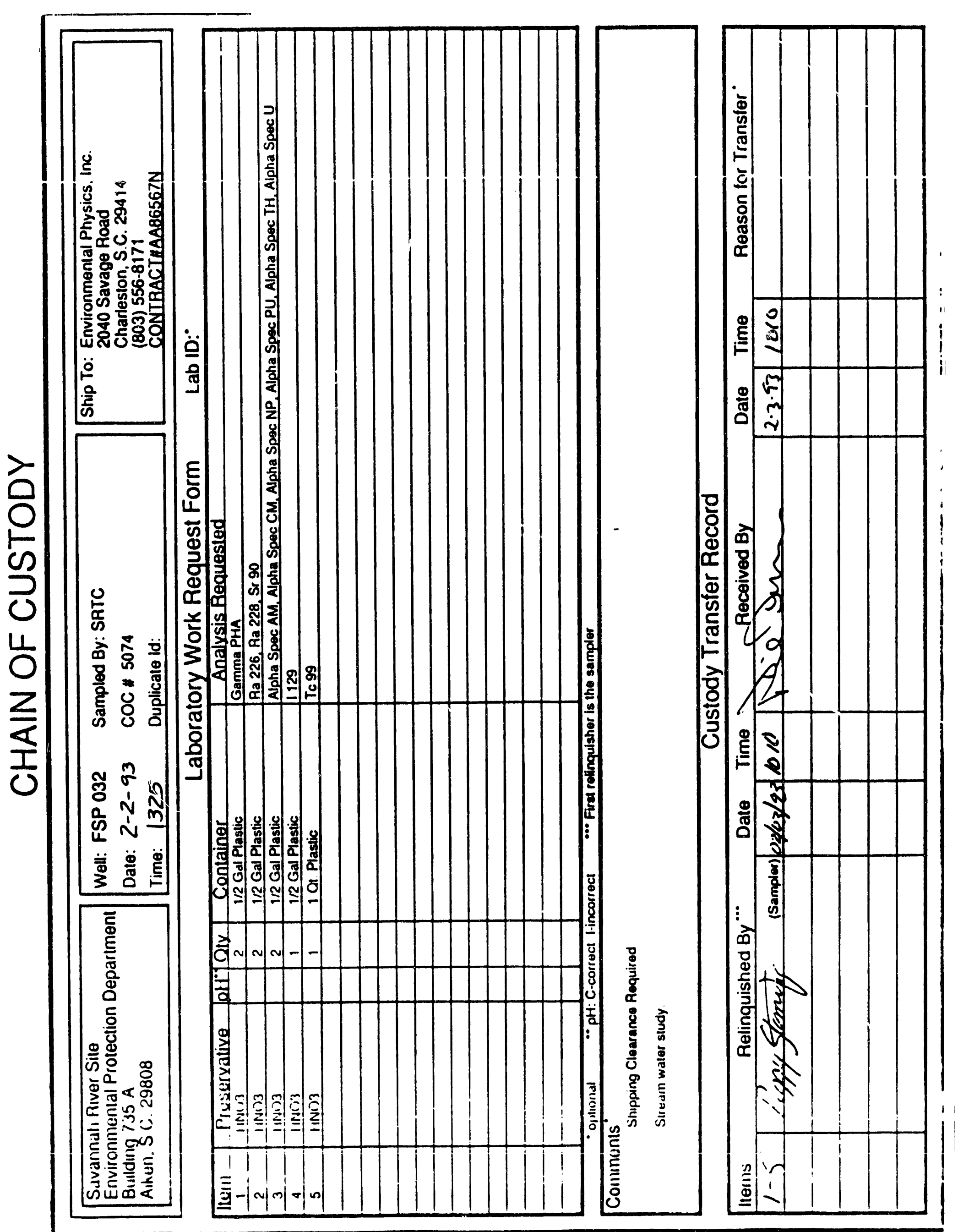




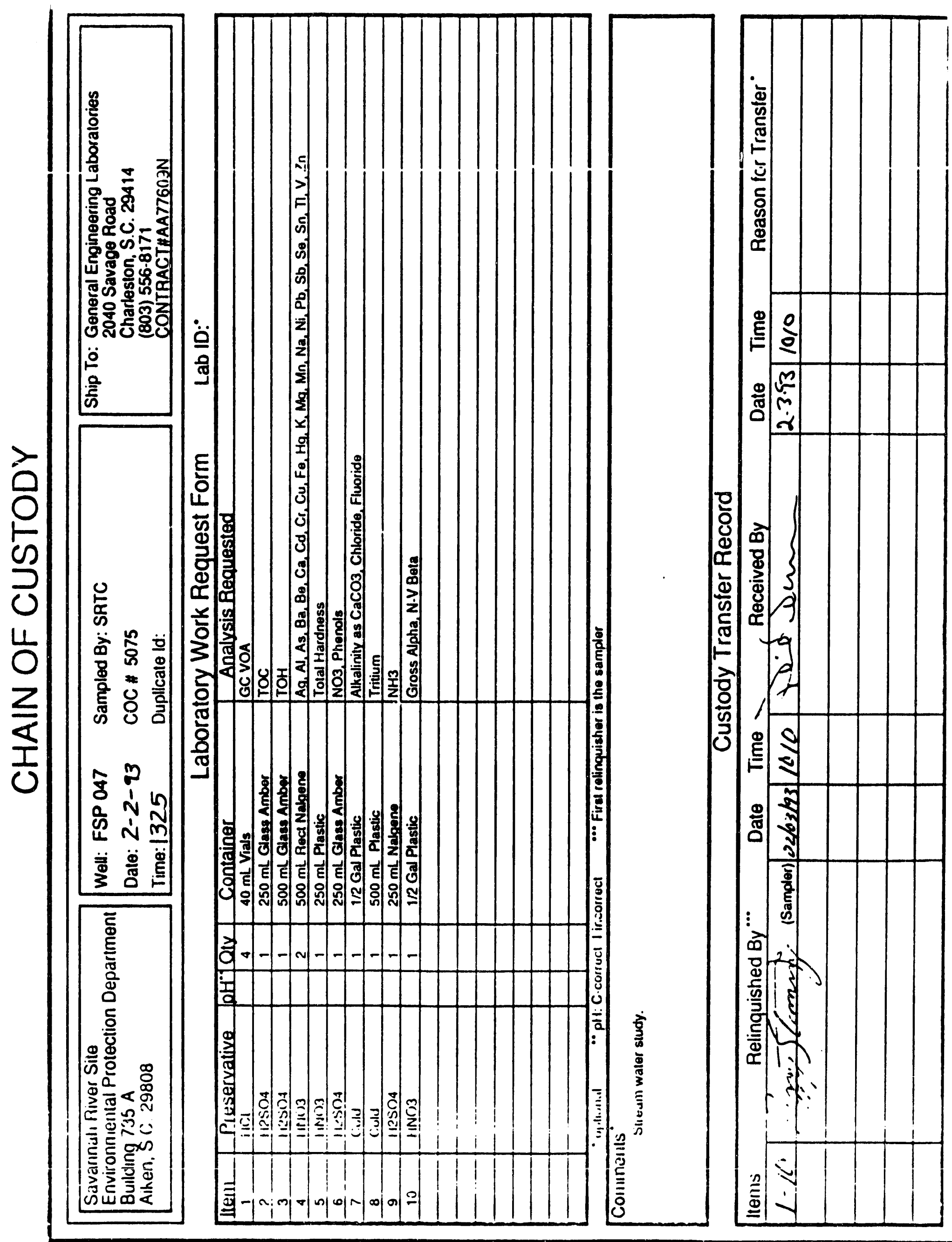




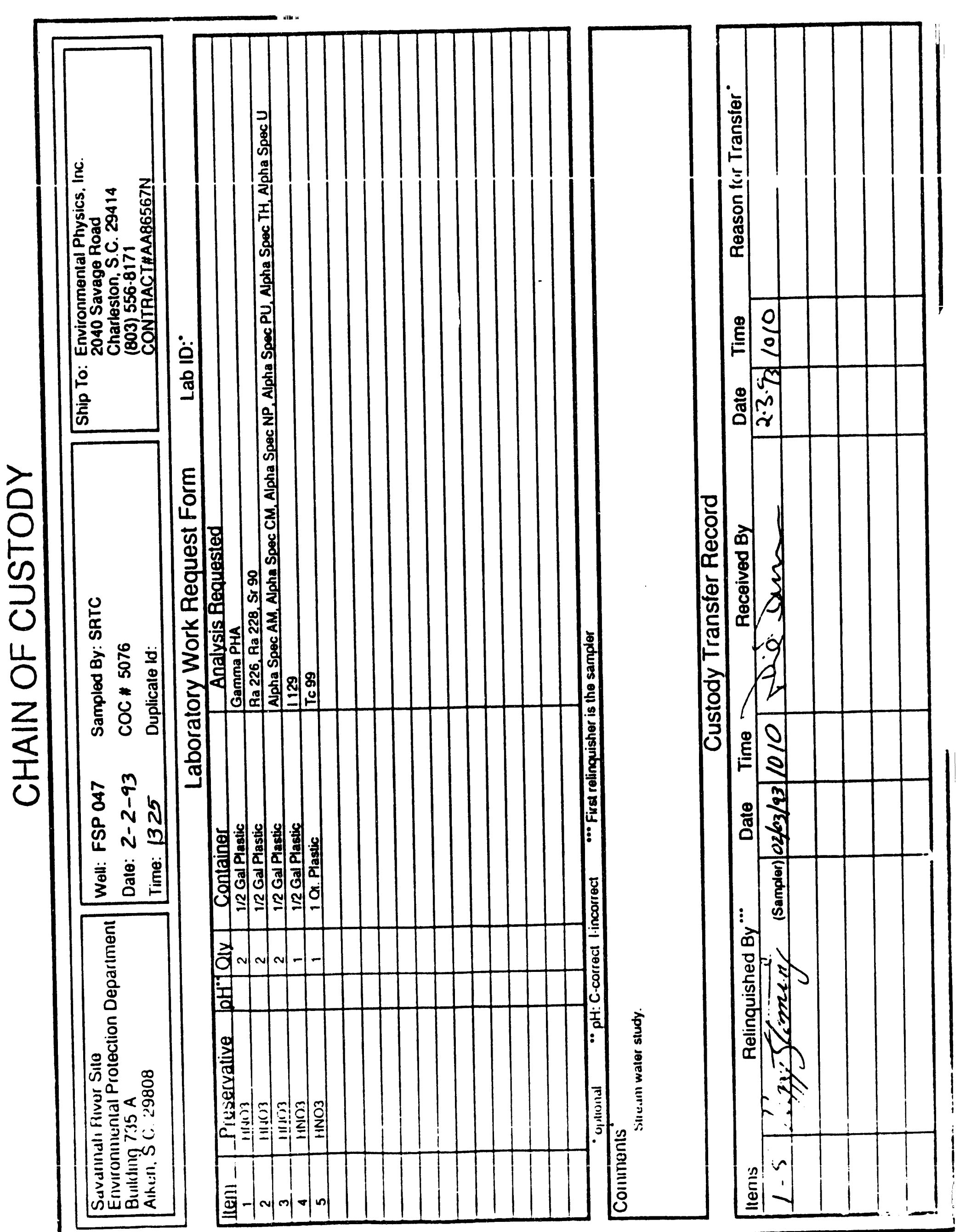




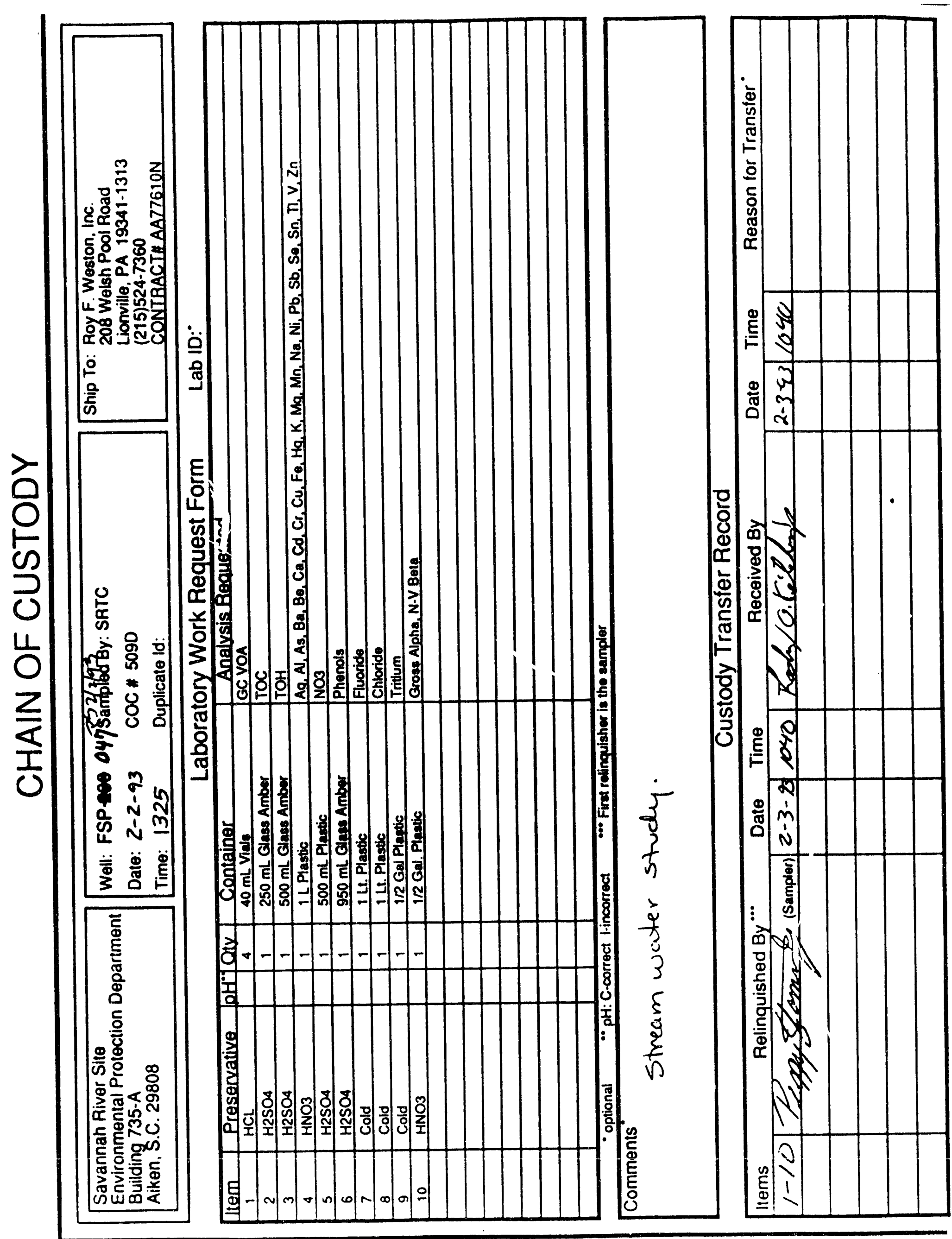




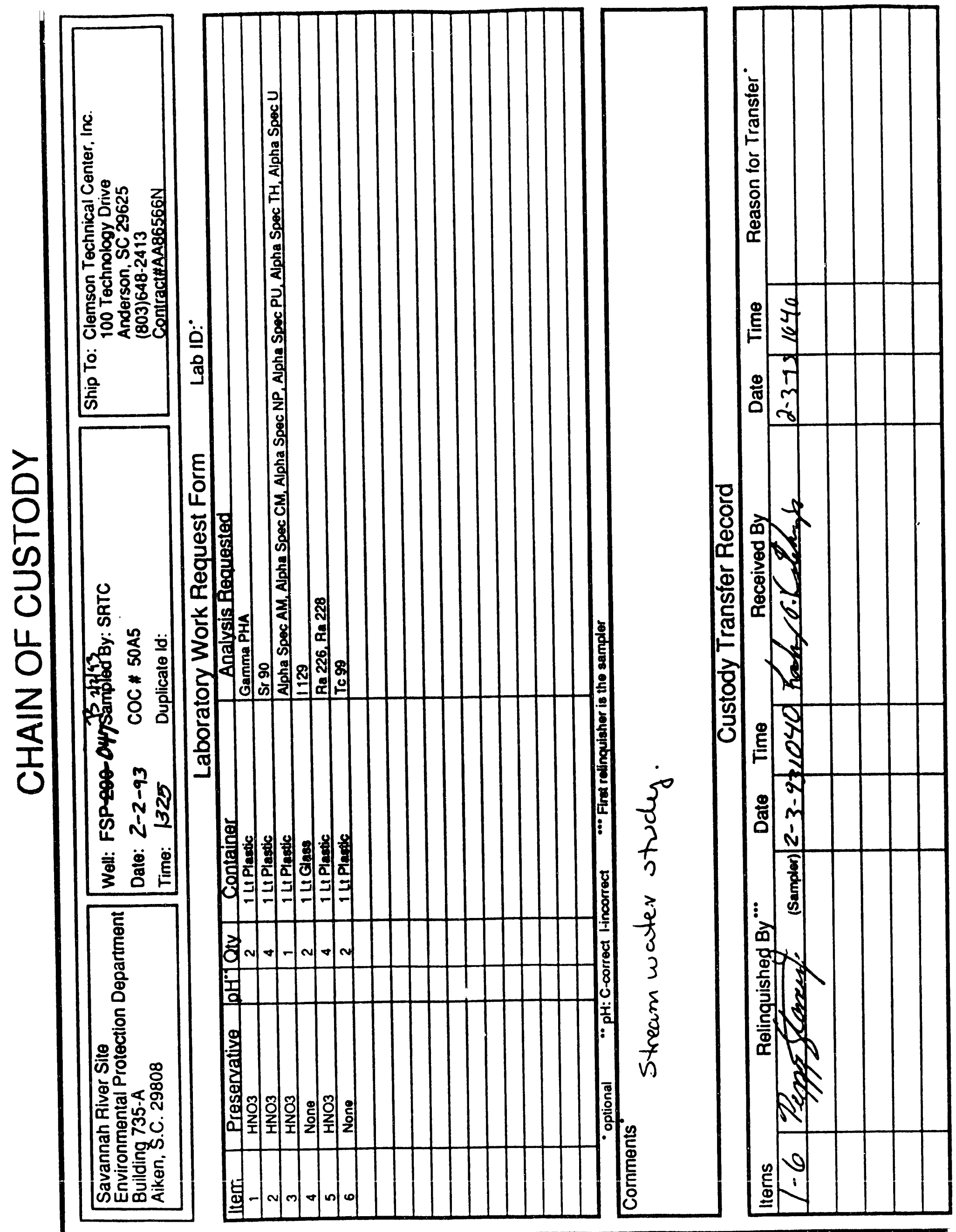




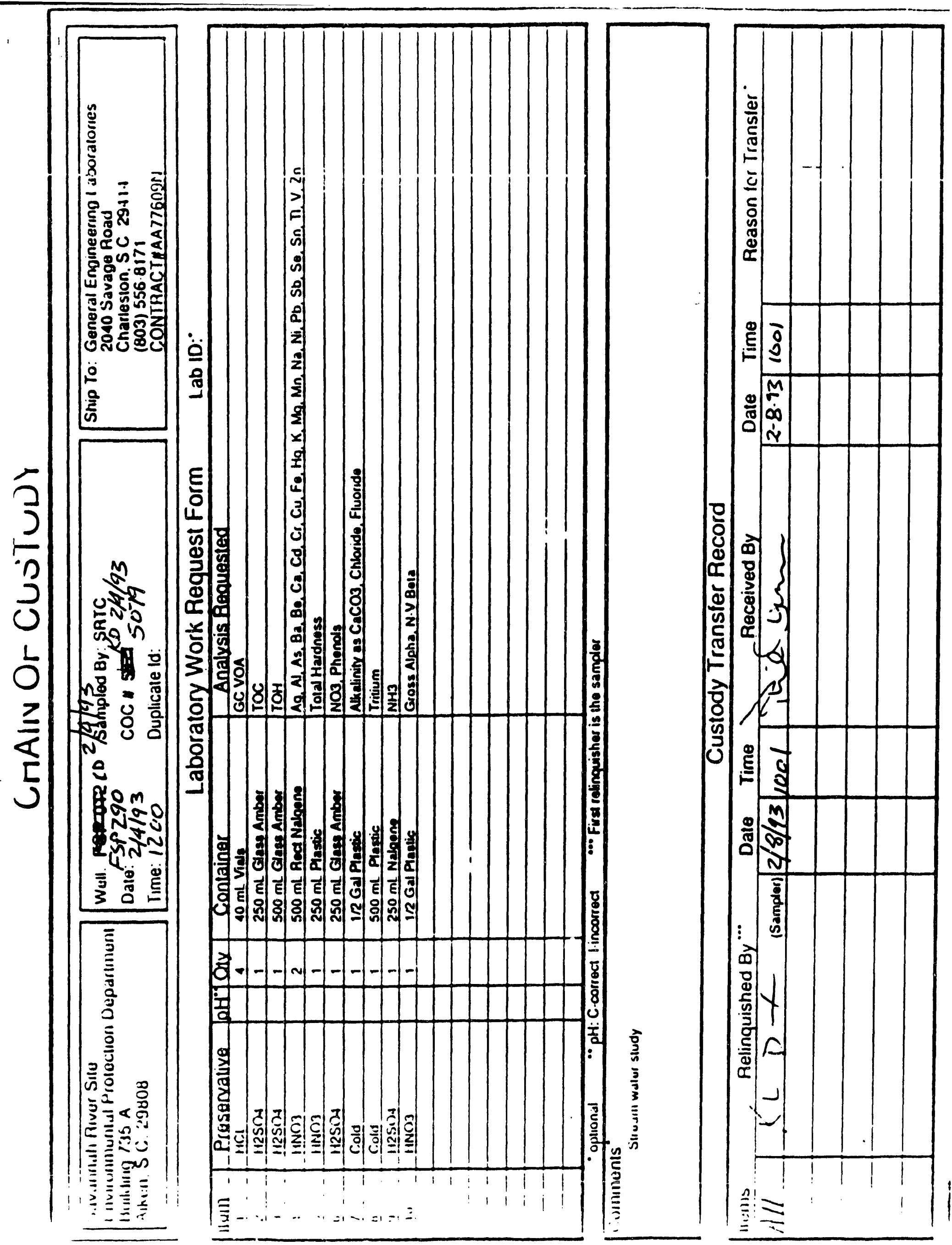




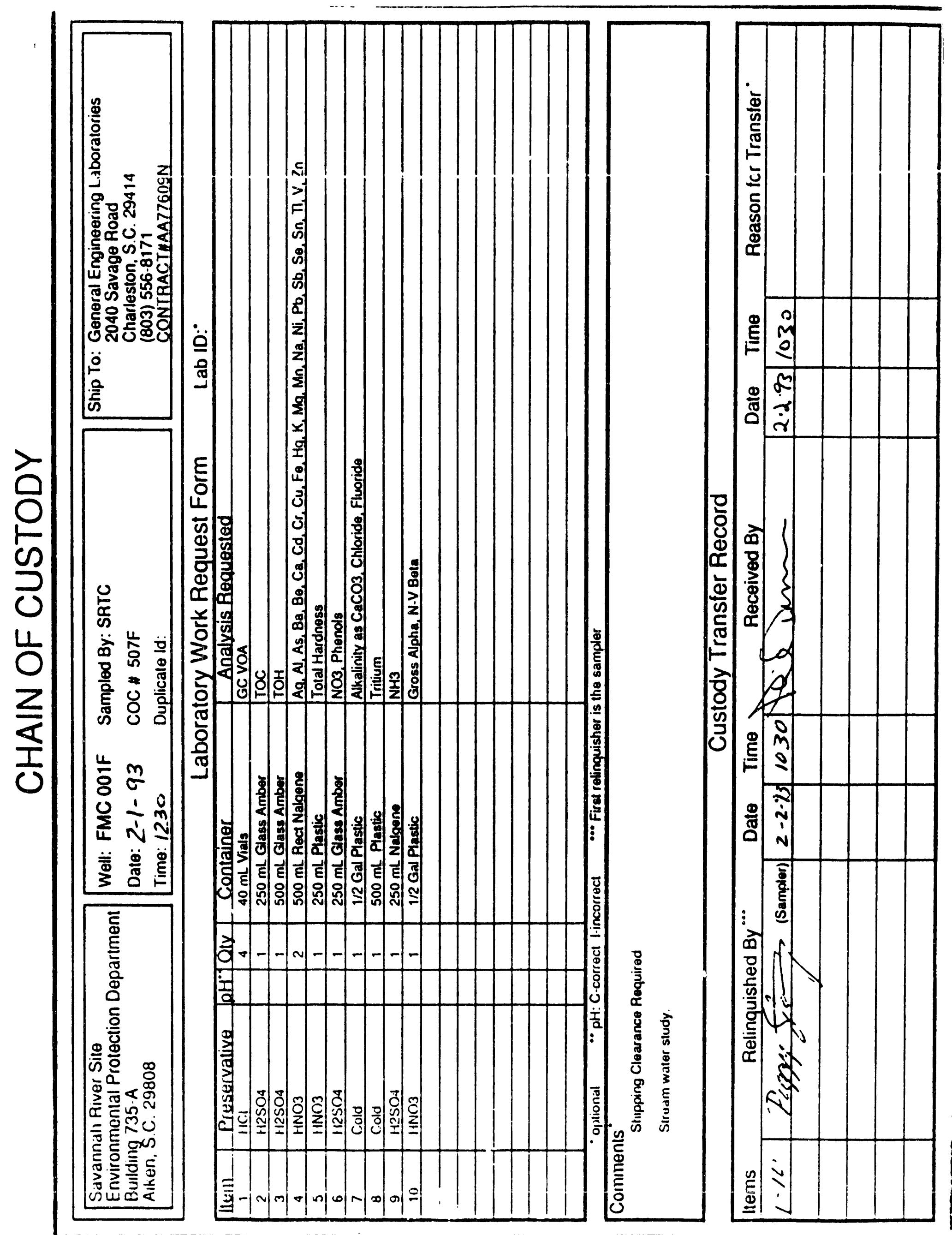




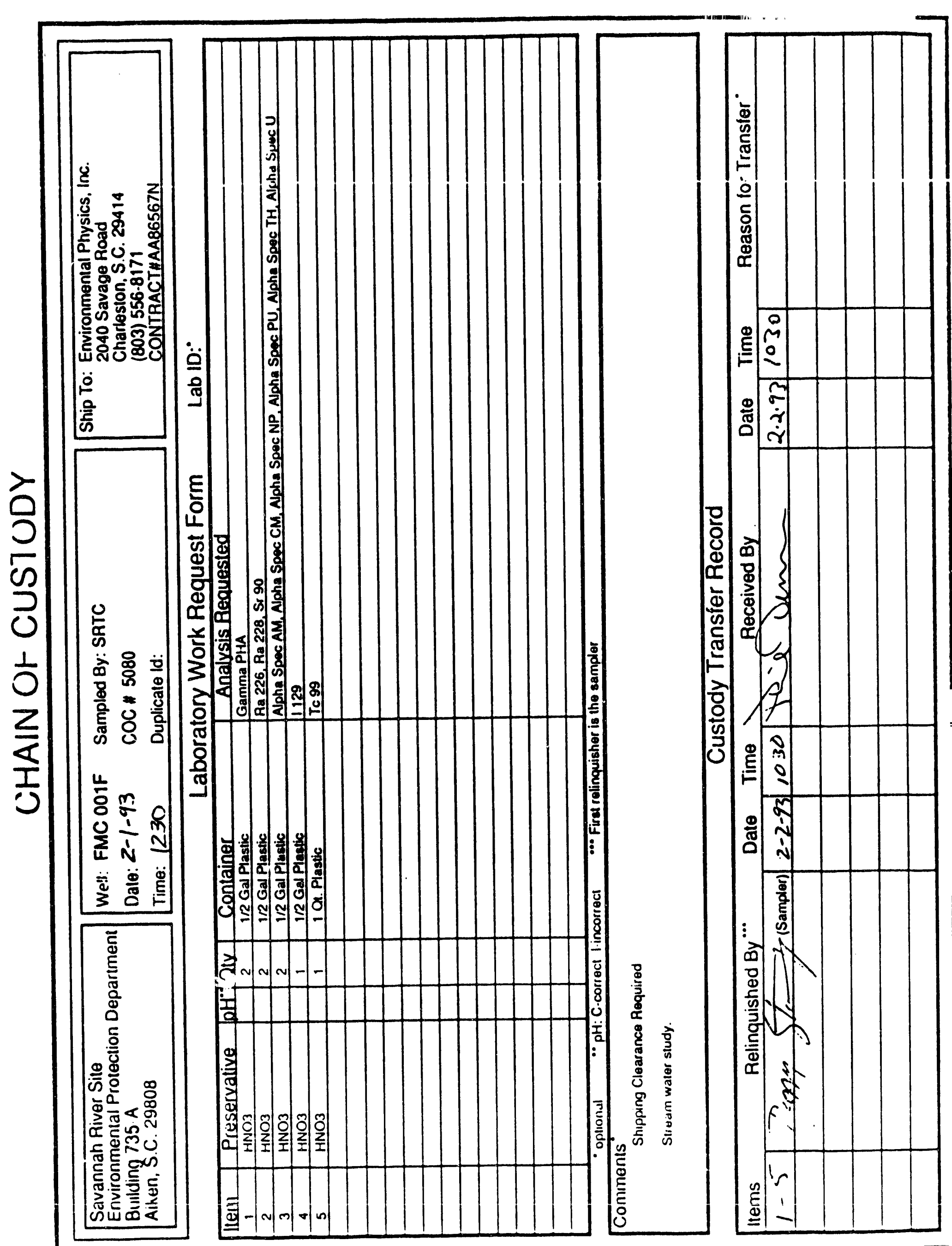




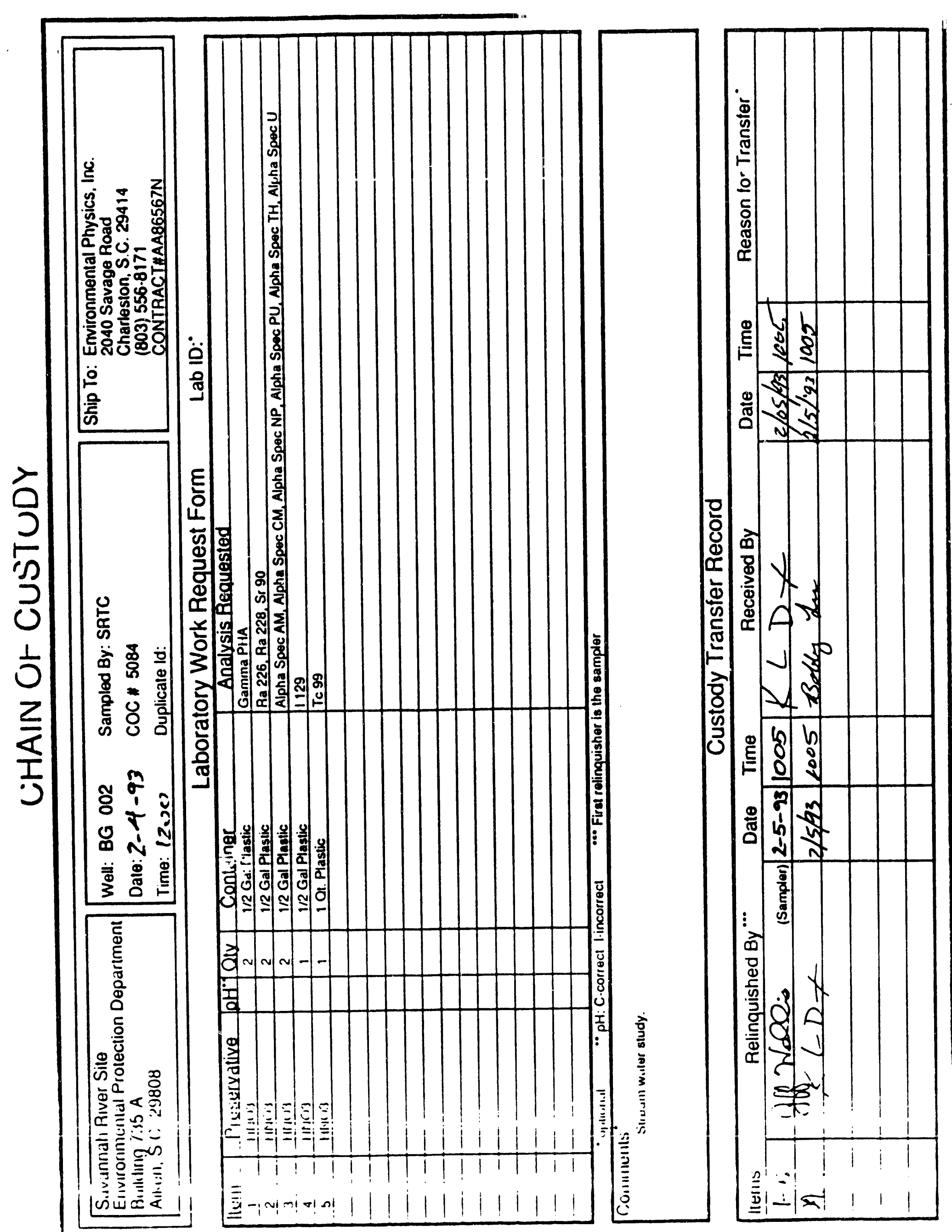




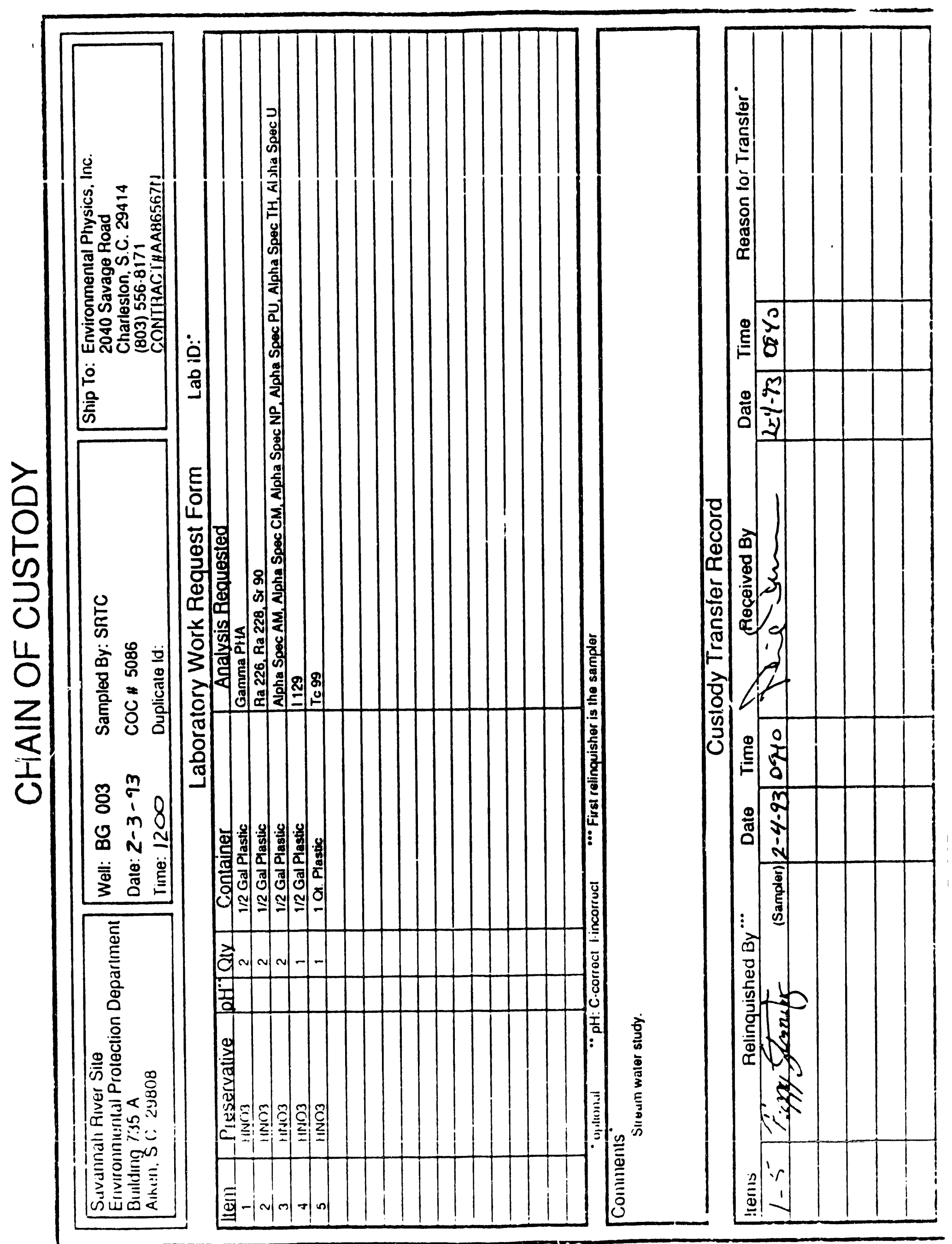




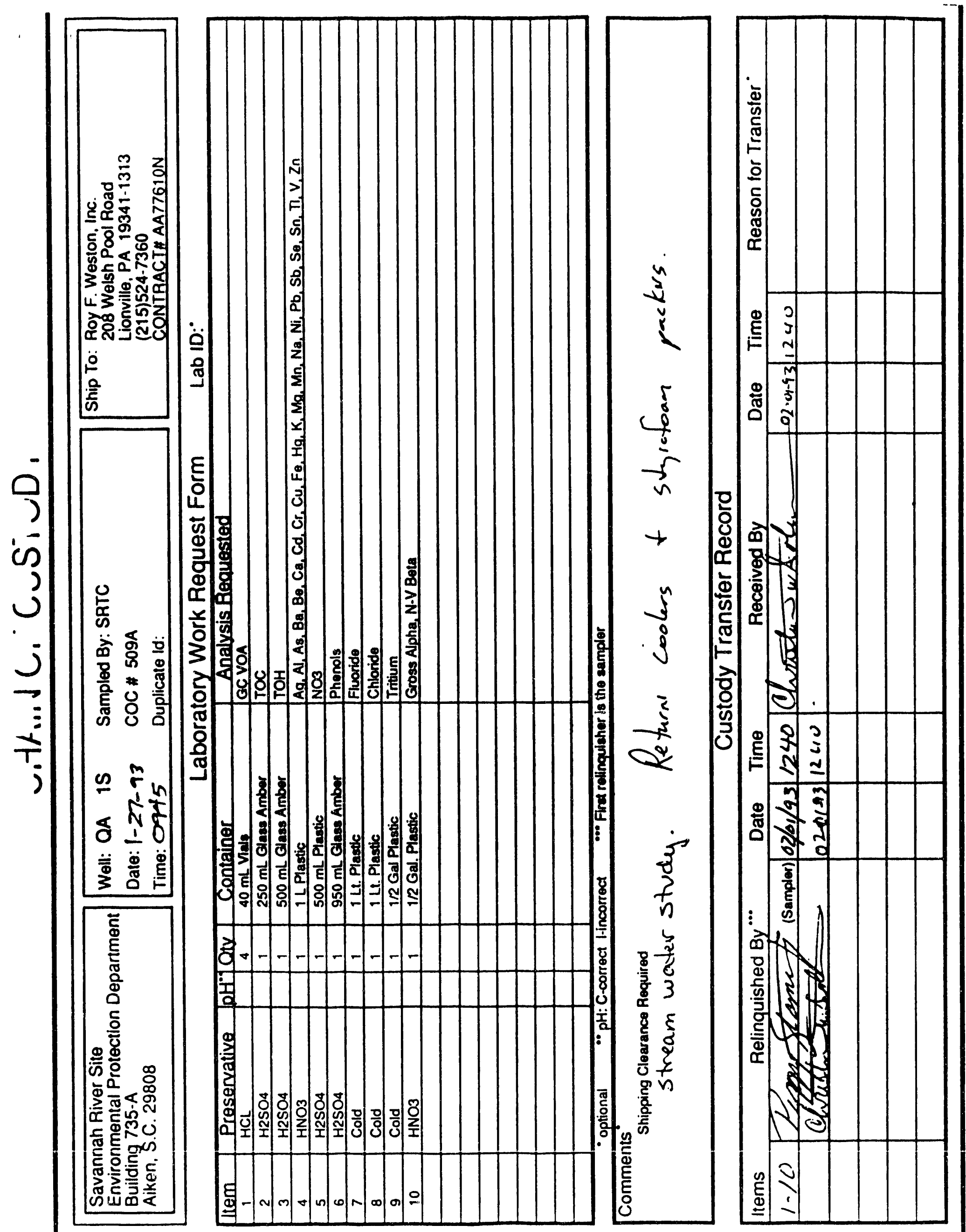




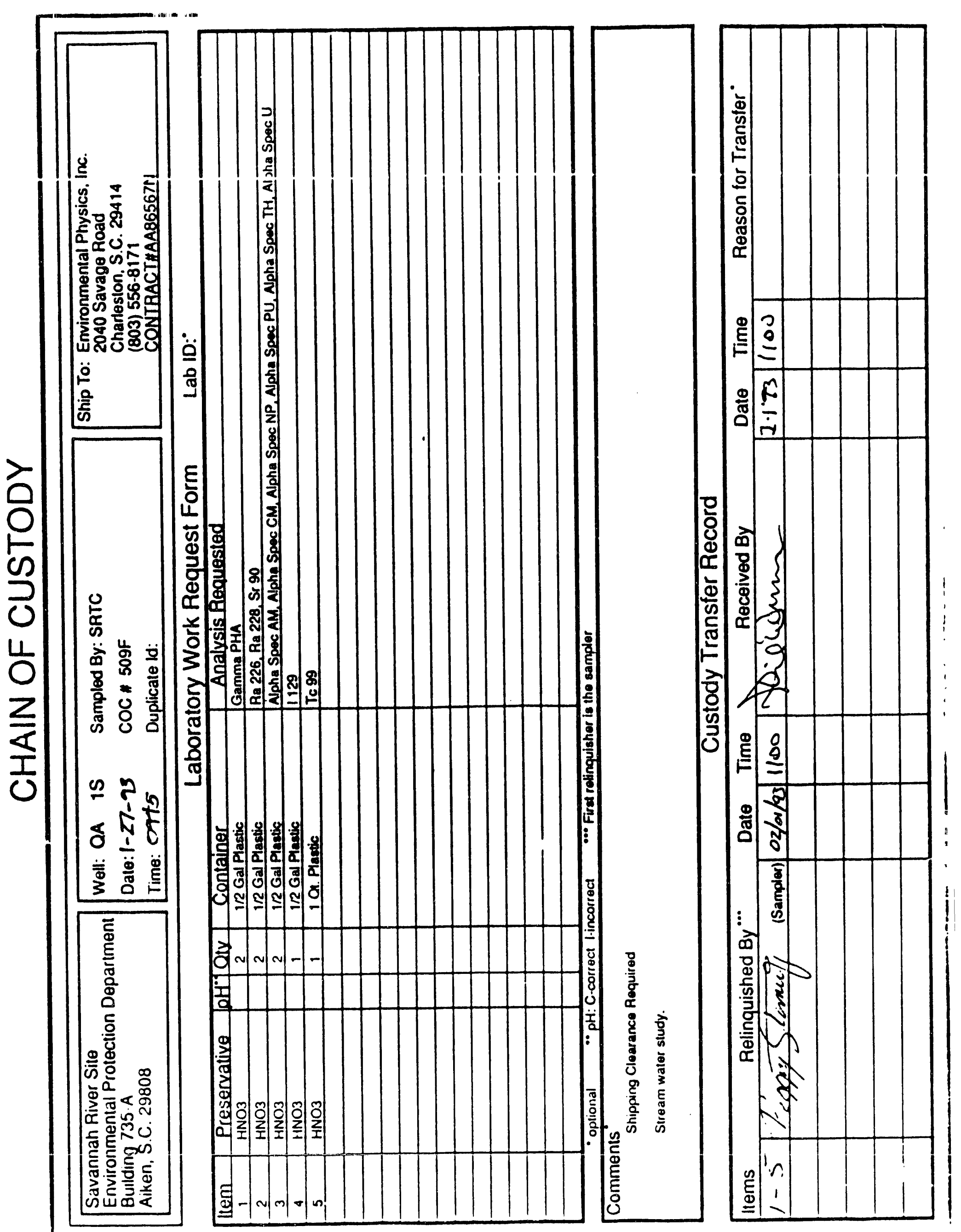




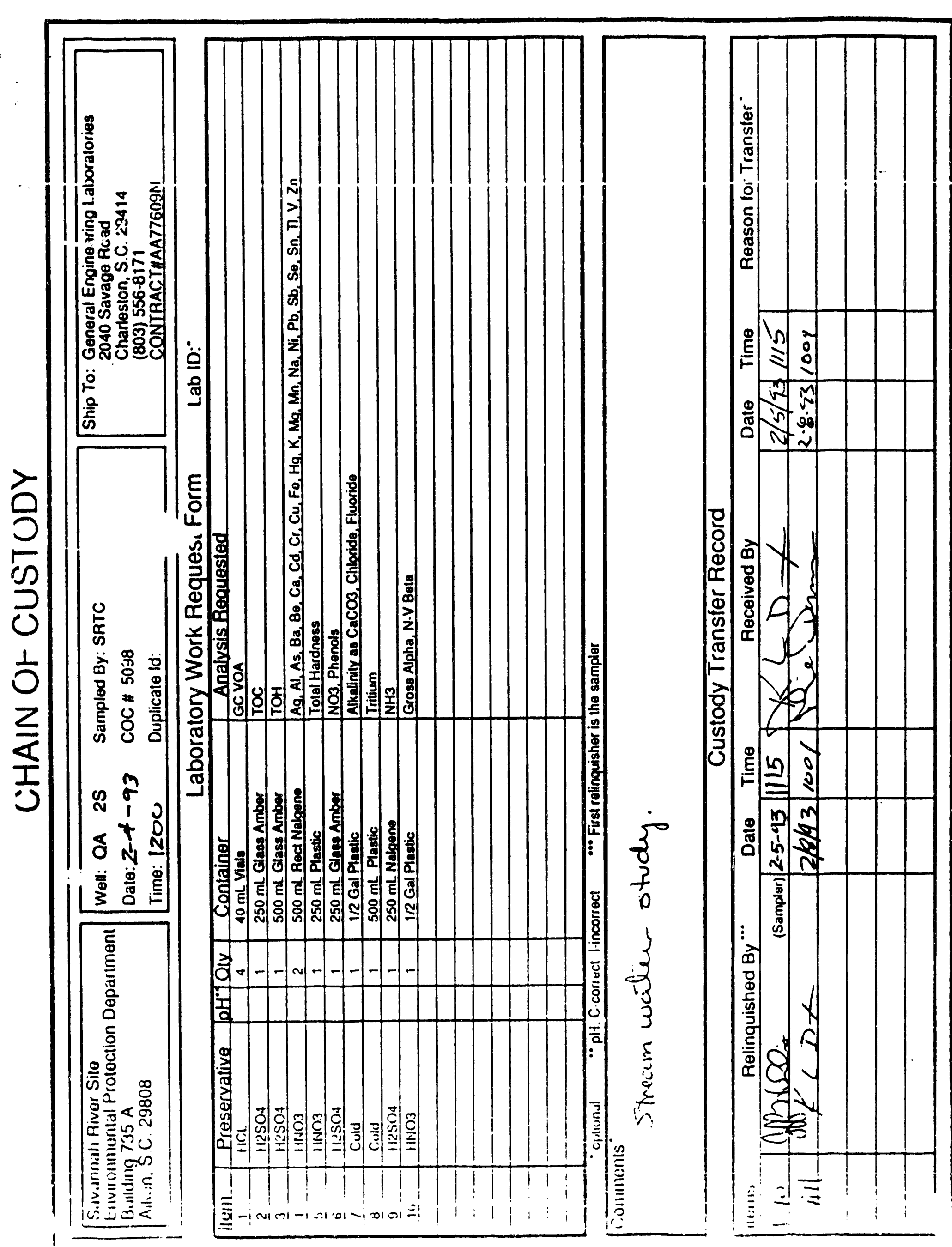




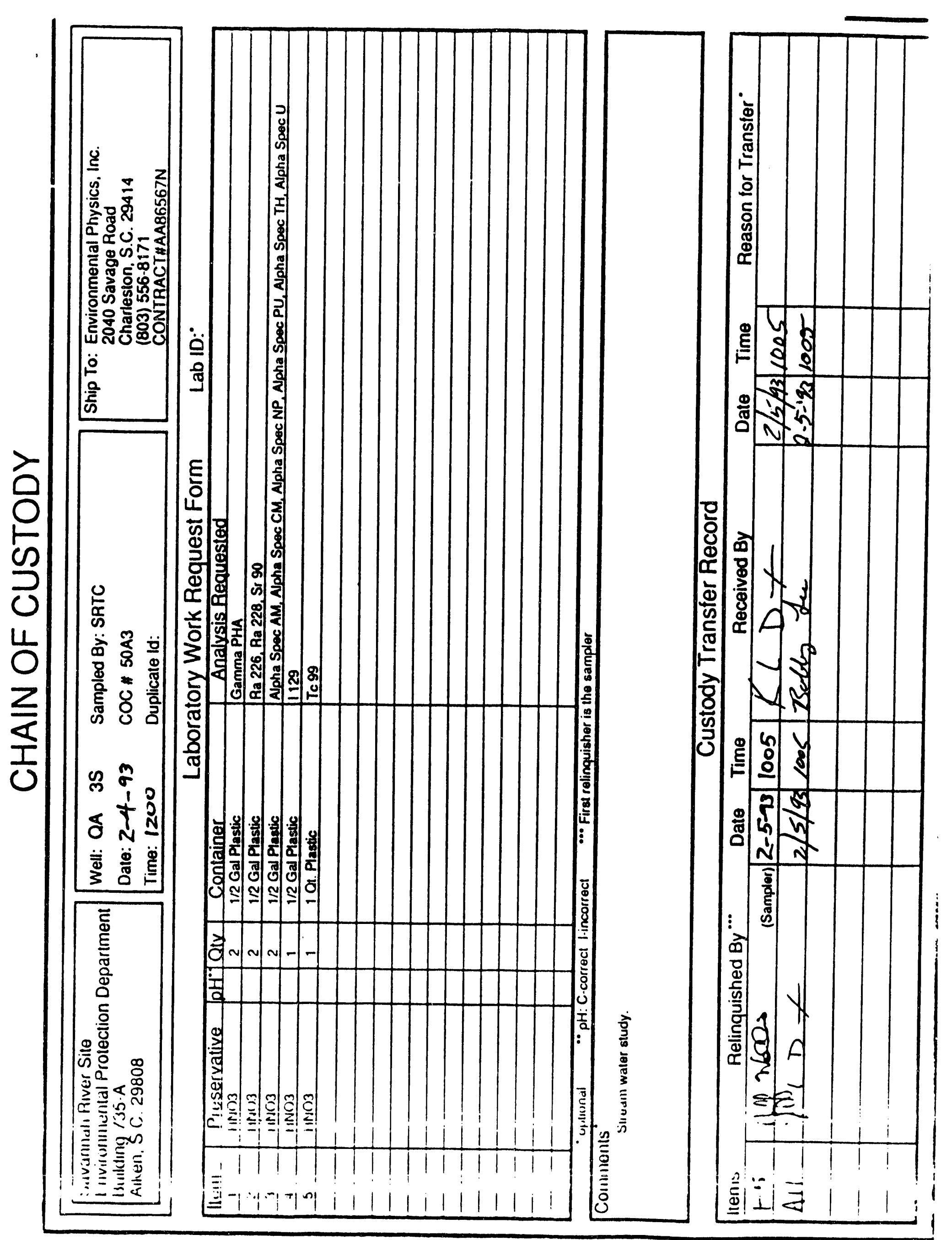




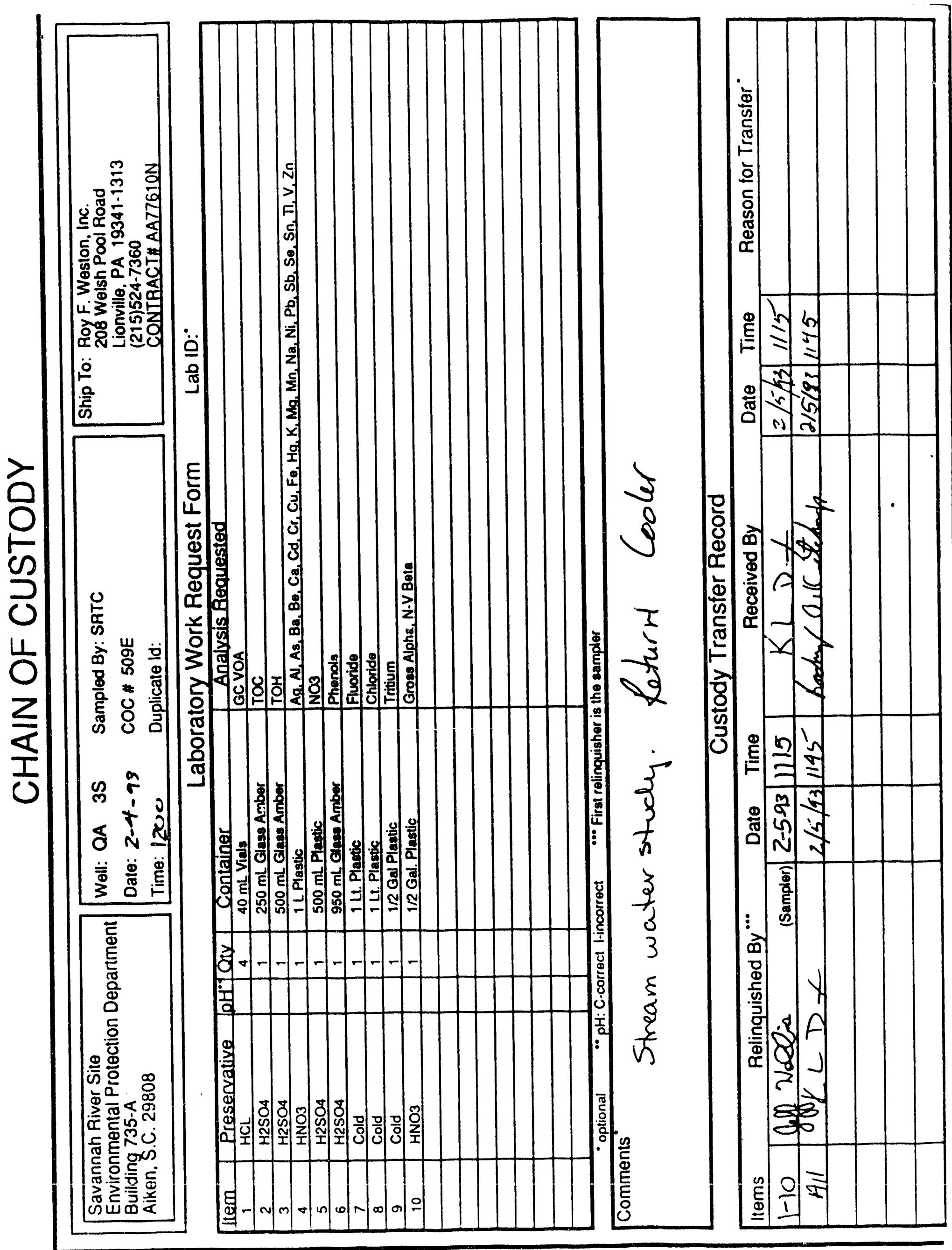




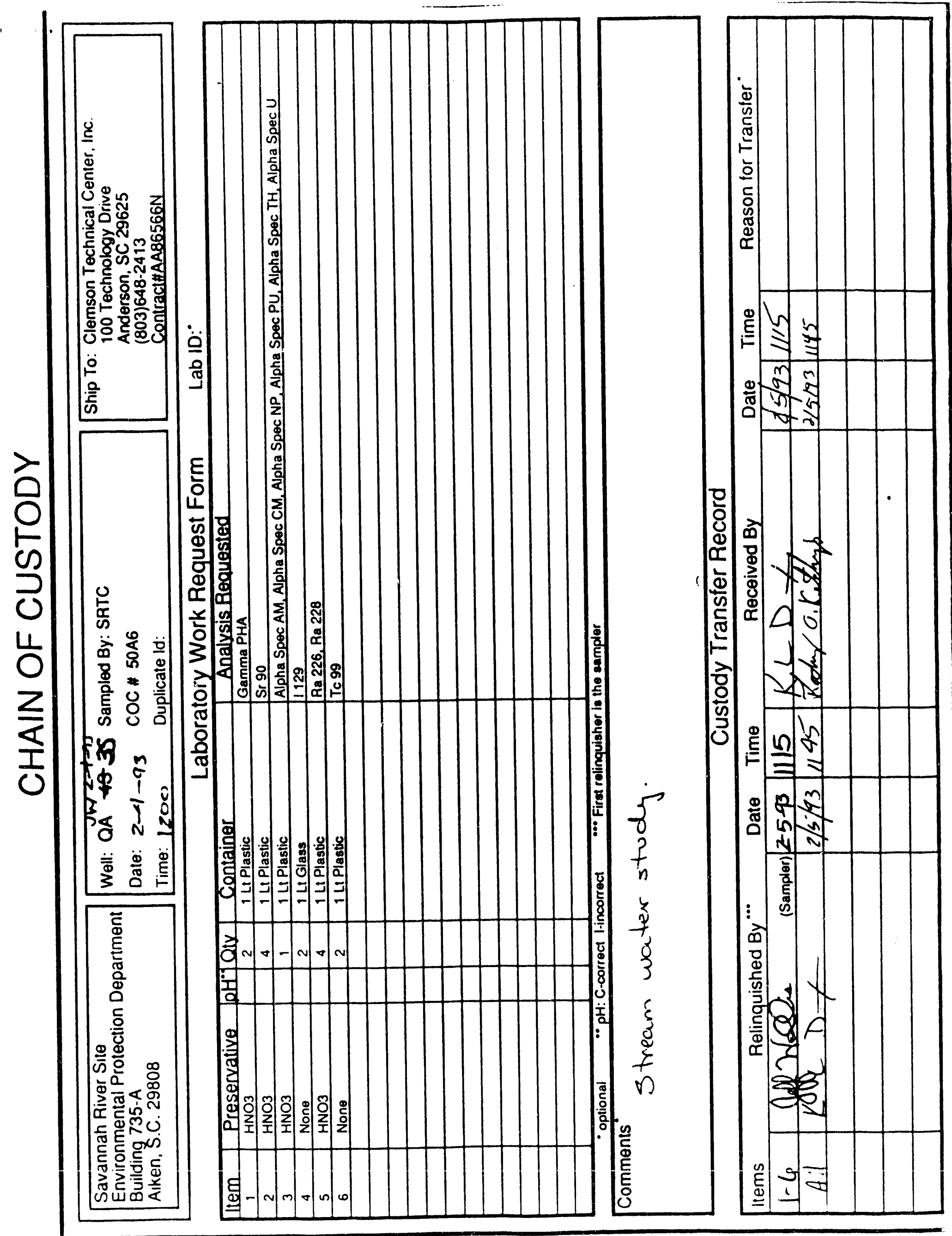




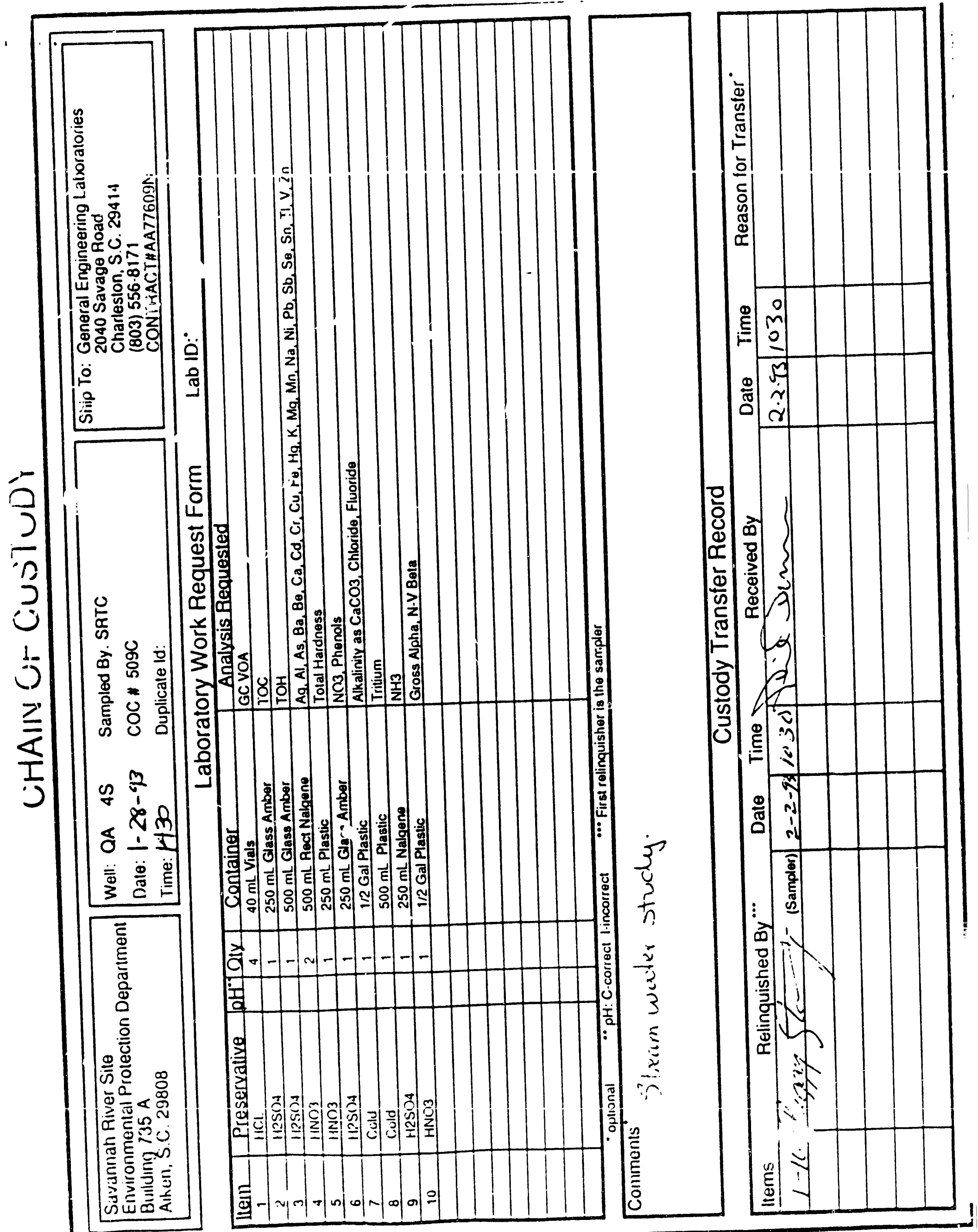




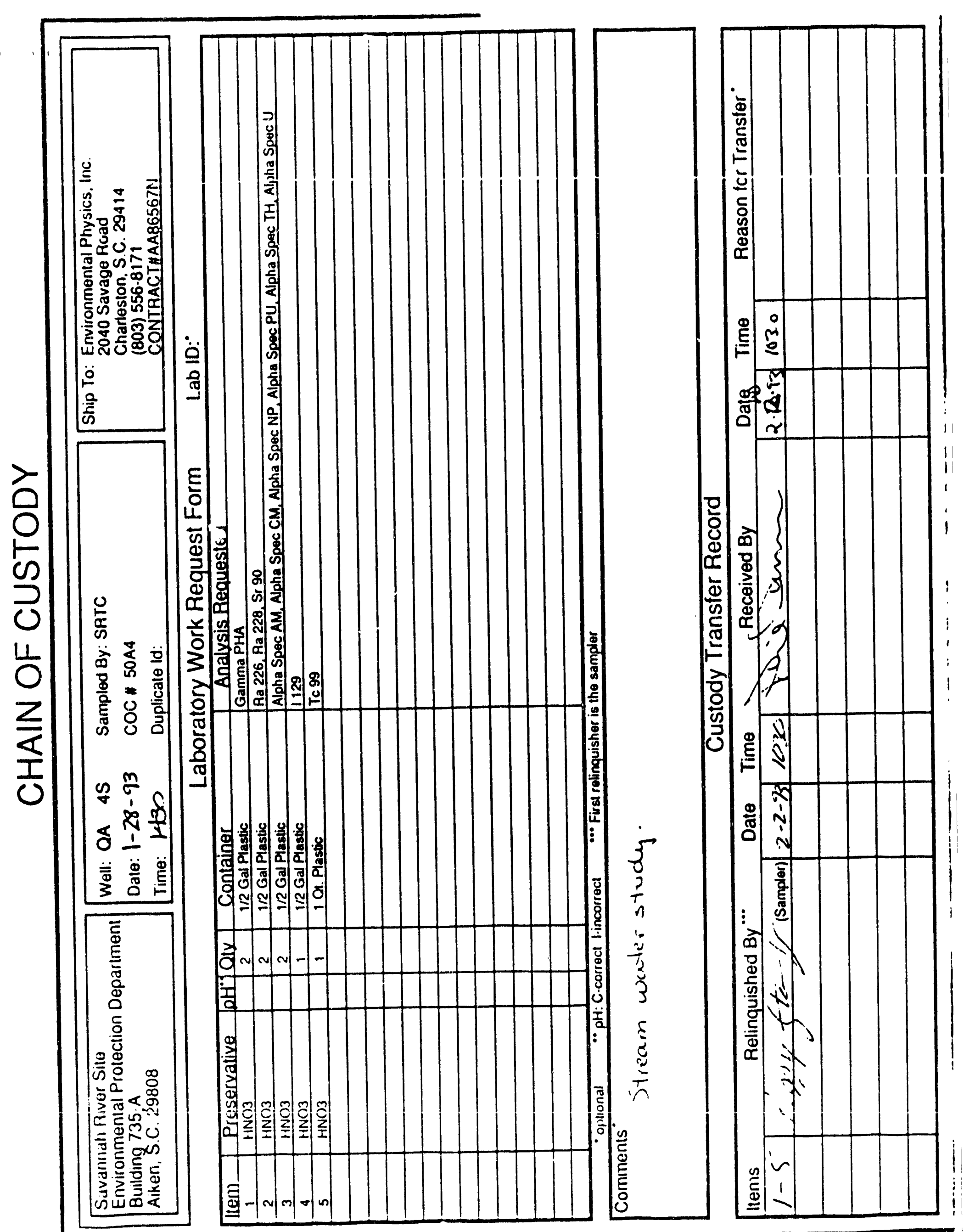




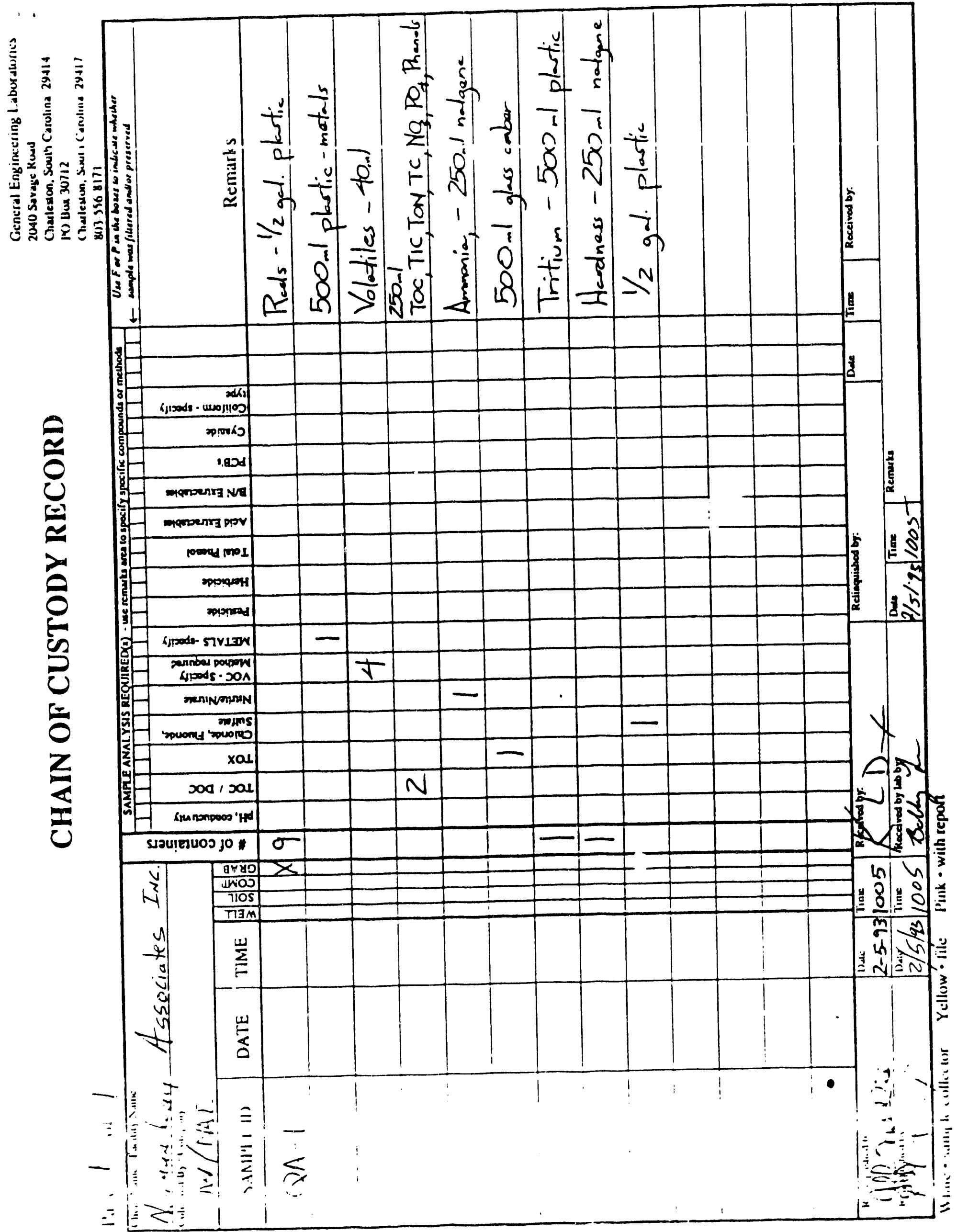




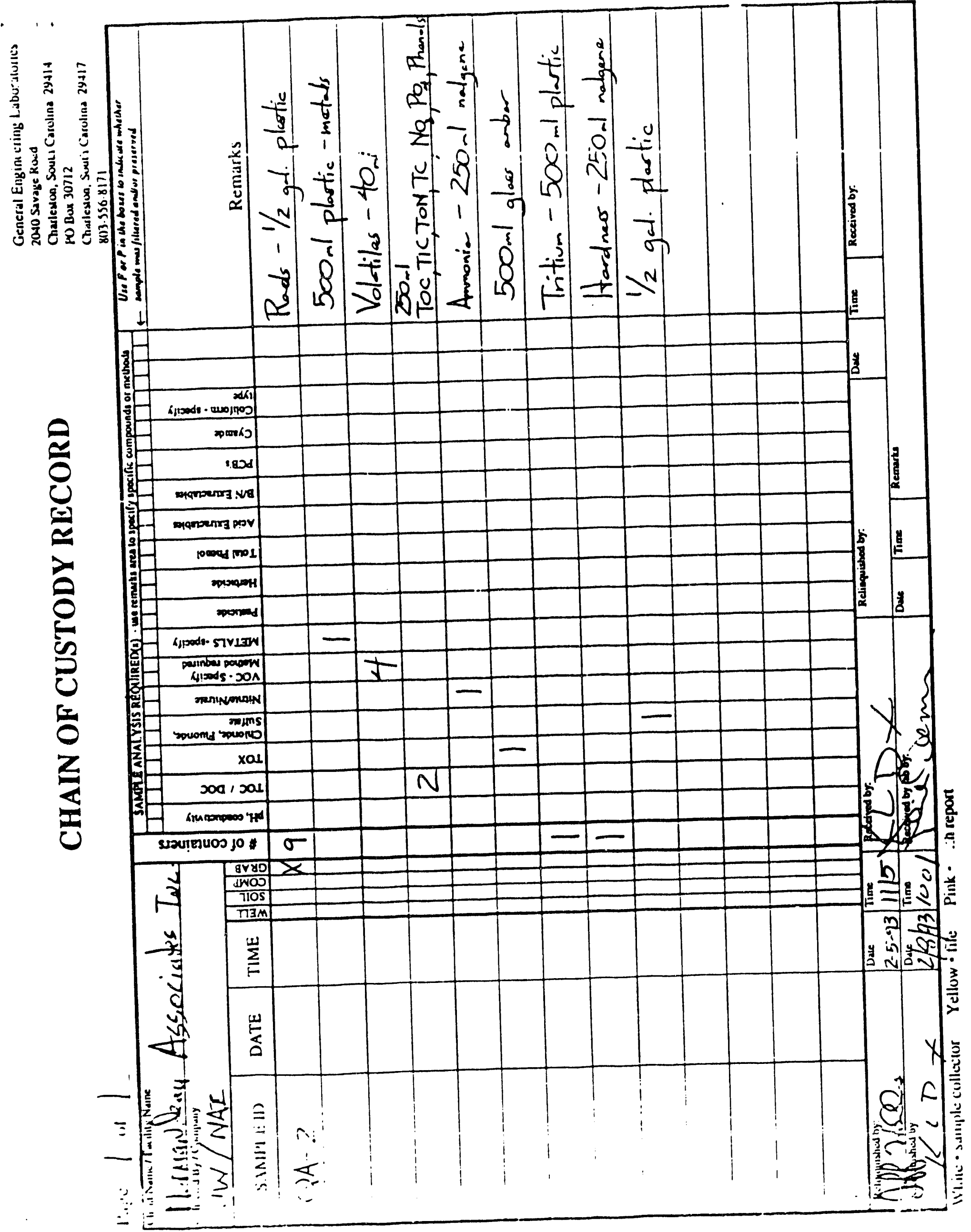




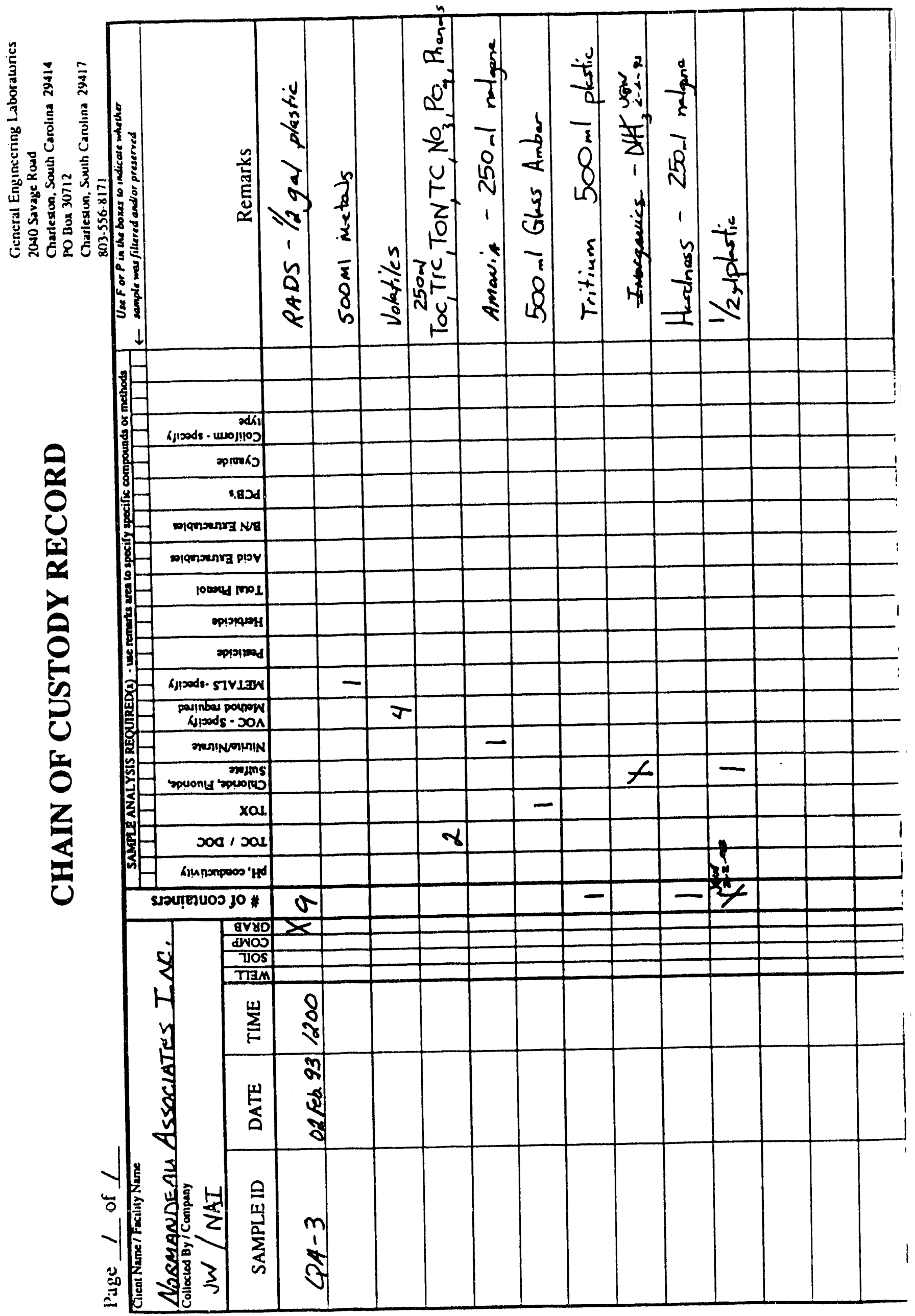




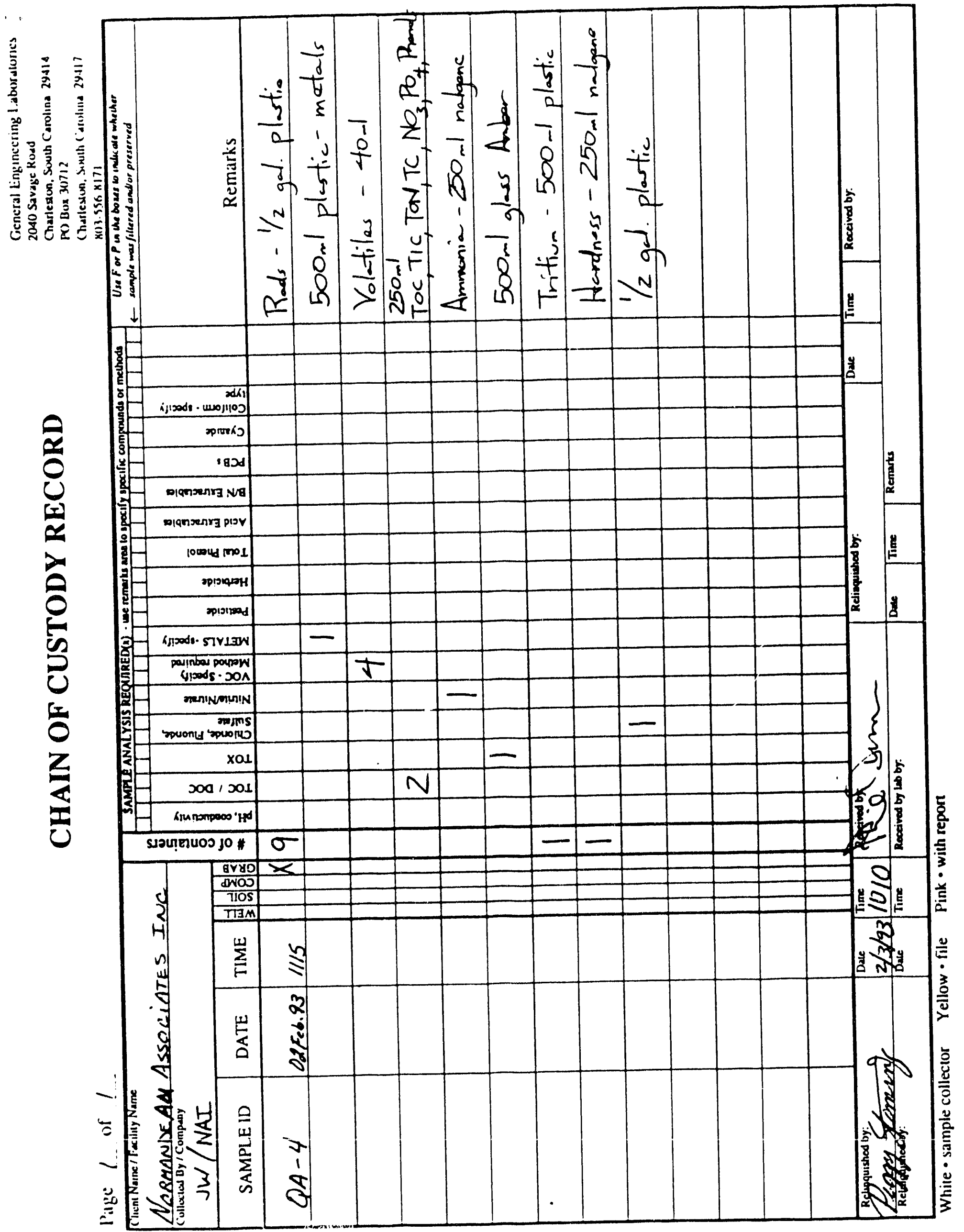


APPENDIX B

Metcalf \& Eddy Surveillance 
July 28,1992

$010005-0001$

To: Gregg Mooney

From: Feter Boucher

Subject: Quality Assurance surveillance for

Four Mile Creek

Task Order No. 26

\section{SURVEILLANCE NARRATIVE}

On Wednesday and Thursday July 22 and 23, 1992, I conducted a quality assurance surveillance of surface and groundwater sampling conducted by Normandeau Associates, Inc. (NAI) at Four Mile creek ahich is currently under investigation under Task Order No. 26. The purpose of the surveillance was to monitor the sampling operation for consistency with quality assurance procedures developed for the project. Accordingly, I checked that the equipment, equipient decontamination, instrument calibration, and sampling procedures, were in conformance with procedures outlined in the Quality Assurance Project Plan prepared by $M \& E$ dated June 1992. I also checked that health and safety proccdures were followed as outlined in the SHERP dated July $10,1392$.

NAI personnel conducting the work included Kathy Herring, Alan Stuart, and Ryan Brady. On Wednesday, I observed the collection of surface water at one station. On rhursday, I observed collection of groundwater at one station where the sampling bucket had been installed on Tuesday.

The surveillance was conducted by reviewing the aforementioned QAPP and generating a series of checklists outlining the critical steps in each phase of the sampling. Actual operations in the field were compared with the checklists. The checklists used and related comments on the operation follow.

\section{CHECKLISTS AND COMMENTS}

Equipment

Field data sheets yes

Prelabeled sample bottles yes

Pump/Battery/Tygon yes

Sample Buckets ( 5 gal) yes

waterproof pens see below

Rubber gloves yes

Water quality meters yes

Hip boots yes

Ice

Filter

Mobile phone

First Aid kit

Fire extinguisher

yes

yes

yes

yes

yes 
comments - The ink used to label the first set of buttles became blurred when the bottles were wet. Permanent markers or ballpoint pens should be used. The MSDS for tritium was not available yet and is to be provided by the STR. An MSDS for Methanol is available in the SHERP.

\section{Instruments}

Calibrate before sampling yes Calibration logbook

yes

Comments - Calibration was conducted before sampling at each station and the results recorded in a logbook.

Sampling Procedures

Bottles have preservative

PVC stake marks station

change tubing at each station

Flush pump for 20 secs between samples

Place samples on ice

$\mathrm{pH} / \mathrm{cond} / \mathrm{orp}$

Sample VOAs and metals first

Bottle marked with station, date and time

Rinse probes with DI between measurements

Metals samples filtered

Do not overflow bottles yes
yes
yes
yes
yes
yes
yes
yes
yes
yes
yes

Comments - The groundwater sample was very turbid and may not accurately reflect the quality of groundwater entering four Mile creek. The samplers attempted lo collect water from the surface, but the turbidity was present throughout the water in the bucket, and may have been caused by the disturbance of installing the bucket, and possibly by a light overnight rain. Material excavated for the bucket was dumped directly adjacent to the hole, possibly contributing to the turbidity. This material should be cast further away from the hole to minimize erosion and turbidity in the event of rain. It should be noted in the lab reports and in the final report that the water quality results were influenced by turbidity resulting from the sampling technique.

A new length of tygon tubing was used for each sample. Part of the surface water filtering was conducted without gloves and several filters were handled with bare hands. Nitrile gloves should be worn whenever hardling samples and during filtering.

Sample bottles were pre-preserved. However, the turbidity of the samples may have added considerable alkalinity. The pH of the samples should be checked and the preservative augmented if necessary. 

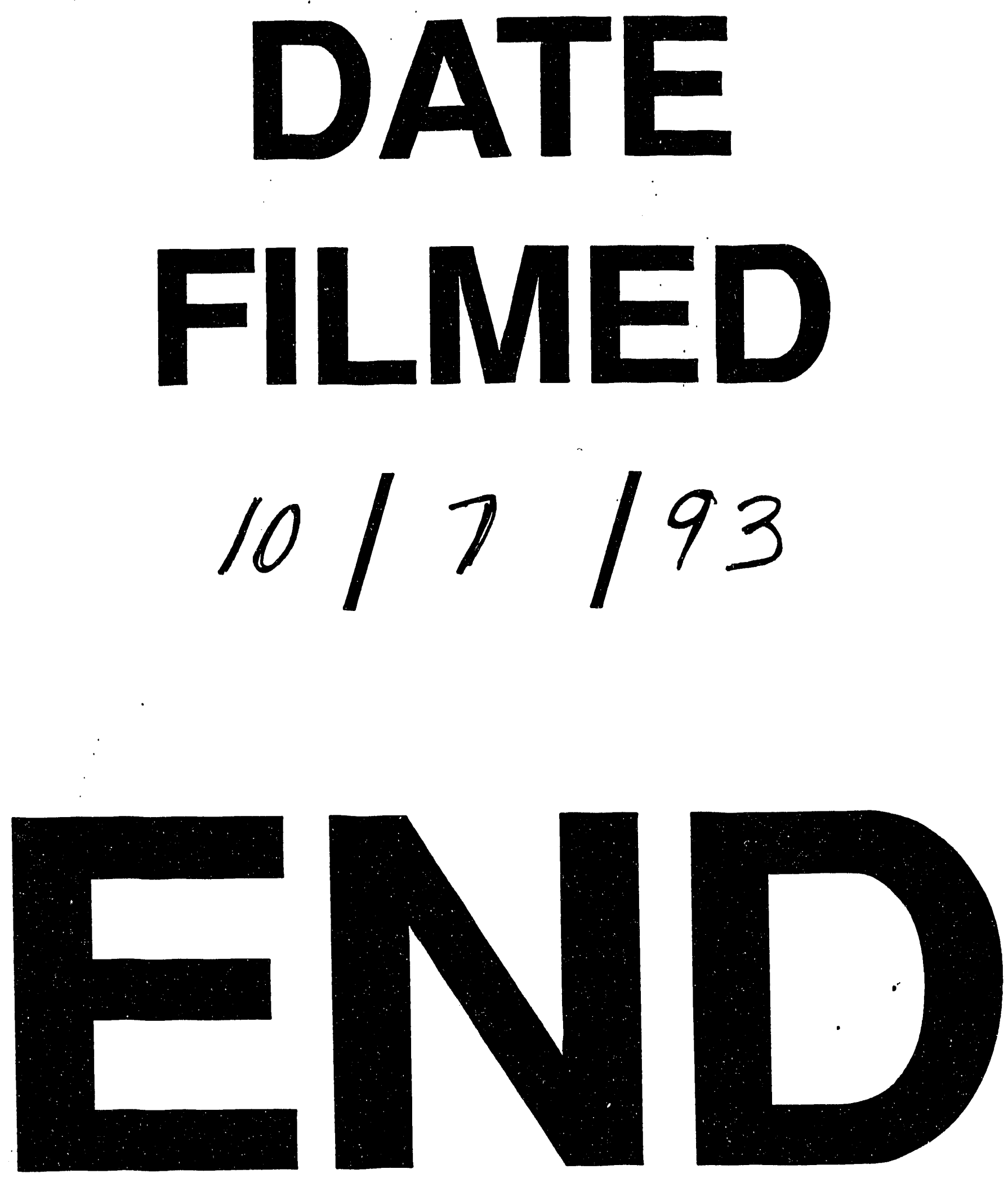
